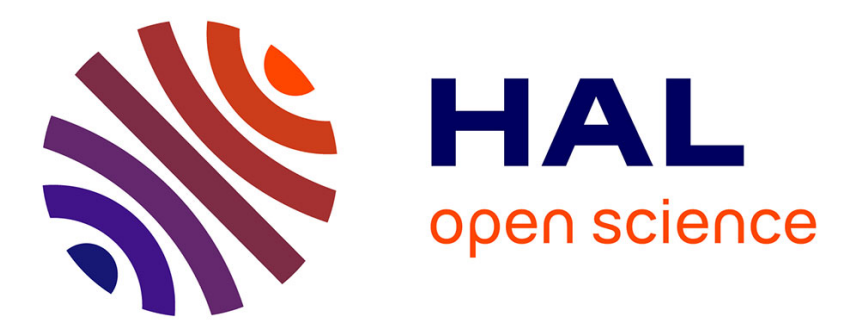

\title{
The four cysteine residues in the second extracellular loop of the human adenosine A receptor: role in ligand binding and receptor function
}

Anke C. Schiedel, Sonja Hinz, Dominik Thimm, Farag Sherbiny, Thomas Borrmann, Astrid Maass, Christa E. Müller

\section{To cite this version:}

Anke C. Schiedel, Sonja Hinz, Dominik Thimm, Farag Sherbiny, Thomas Borrmann, et al.. The four cysteine residues in the second extracellular loop of the human adenosine A receptor: role in ligand binding and receptor function. Biochemical Pharmacology, 2011, 82 (4), pp.389. 10.1016/j.bcp.2011.05.008 . hal-00718035

\section{HAL Id: hal-00718035 \\ https://hal.science/hal-00718035}

Submitted on 16 Jul 2012

HAL is a multi-disciplinary open access archive for the deposit and dissemination of scientific research documents, whether they are published or not. The documents may come from teaching and research institutions in France or abroad, or from public or private research centers.
L'archive ouverte pluridisciplinaire HAL, est destinée au dépôt et à la diffusion de documents scientifiques de niveau recherche, publiés ou non, émanant des établissements d'enseignement et de recherche français ou étrangers, des laboratoires publics ou privés. 


\section{Accepted Manuscript}

Title: The four cysteine residues in the second extracellular loop of the human adenosine $A_{2 B}$ receptor: role in ligand binding and receptor function

Authors: Anke C. Schiedel, Sonja Hinz, Dominik Thimm, Farag Sherbiny, Thomas Borrmann, Astrid Maaß, Christa E.

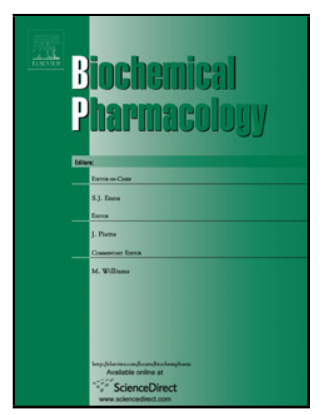

Müller

PII:

S0006-2952(11)00301-7

DOI:

Reference: doi:10.1016/j.bcp.2011.05.008

BCP 10900

To appear in: $\quad B C P$

Received date: $\quad$ 18-2-2011

Revised date: $\quad 9-5-2011$

Accepted date: $\quad$ 11-5-2011

Please cite this article as: Schiedel AC, Hinz S, Thimm D, Sherbiny F, Borrmann T, Maaß A, Müller CE, The four cysteine residues in the second extracellular loop of the human adenosine $A_{2 B}$ receptor: role in ligand binding and receptor function, Biochemical Pharmacology (2010), doi:10.1016/j.bcp.2011.05.008

This is a PDF file of an unedited manuscript that has been accepted for publication. As a service to our customers we are providing this early version of the manuscript. The manuscript will undergo copyediting, typesetting, and review of the resulting proof before it is published in its final form. Please note that during the production process errors may be discovered which could affect the content, and all legal disclaimers that apply to the journal pertain. 


\title{
The four cysteine residues in the second extracellular loop of the human adenosine $A_{2 B}$ receptor: role in ligand binding and receptor function
}

\author{
Anke C. Schiedel ${ }^{a, \star}$, Sonja Hinz ${ }^{\mathrm{a}}$, Dominik Thimm ${ }^{\mathrm{a}}$, Farag Sherbiny ${ }^{\mathrm{b}}$, Thomas \\ Borrmann $^{\mathrm{a}}$, Astrid Maaß ${ }^{\mathrm{b}}$, and Christa E. Müller ${ }^{\mathrm{a}}$ \\ aPharmaCenter Bonn, Pharmaceutical Institute, Pharmaceutical Chemistry I, University \\ of Bonn, An der Immenburg 4, D-53121 Bonn, Germany \\ ${ }^{\mathrm{b}}$ Fraunhofer Institute SCAI, Schloss Birlinghoven, 53754 Sankt Augustin, Germany \\ *corresponding author: schiedel@uni-bonn.de, phone ++49 (228) 736457; fax ++49 \\ (228) 732567; An der Immenburg 4, D-53121 Bonn, Germany \\ shinz@uni-bonn.de, dthimm@uni-bonn.de, fselim@uni-bonn.de, \\ thomas.borrmann@uni-bonn.de, astrid.maass@scai.fraunhofer.de, \\ christa.mueller@uni-bonn.de
}

category: (5) Inflammation and Immunopharmacology 


\section{Abstract}

The adenosine $A_{2 B}$ receptor is of considerable interest as a new drug target for the treatment of asthma, inflammatory diseases, pain, and cancer. In the present study we investigated the role of the cysteine residues in the extracellular loop 2 (ECL2) of the receptor, which is particularly cysteine-rich, by a combination of mutagenesis, molecular modeling, chemical and pharmacological experiments. Pretreatment of $\mathrm{CHO}$ cells recombinantly expressing the human $A_{2 B}$ receptor with dithiothreitol led to a 74-fold increase in the $\mathrm{EC}_{50}$ value of the agonist NECA in cyclic AMP accumulation. In the $\mathrm{C} 78^{3.25} \mathrm{~S}$ and the $\mathrm{C} 171^{45.50} \mathrm{~S}$ mutants high-affinity binding of the $\mathrm{A}_{2 \mathrm{~B}}$ antagonist radioligand $\left[{ }^{3} \mathrm{H}\right] \mathrm{PSB}-603$ was abolished and agonists were virtually inactive in cAMP assays. This indicates that the C3.25-C45.50 disulfide bond, which is highly conserved in GPCRs, is also important for binding and function of $A_{2 B}$ receptors. In contrast, the $\mathrm{C} 166^{45.45} \mathrm{~S}$ and the $\mathrm{C} 167^{45.46} \mathrm{~S}$ mutants as well as the $\mathrm{C} 166^{45.45} \mathrm{~S}-\mathrm{C} 167^{45.46} \mathrm{~S}$ double mutant behaved like the wild-type receptor, while in the $\mathrm{C} 154^{45.33} \mathrm{~S}$ mutant significant, although more subtle effects on cAMP accumulation were observed - decrease (BAY606583 ) or increase (NECA) - depending on the structure of the investigated agonist. In contrast to the X-ray structure of the closely related $A_{2 A}$ receptor, which showed four disulfide bonds, the present data indicate that in the $A_{2 B}$ receptor only the C3.25-C45.50 disulfide bond is essential for ligand binding and receptor activation. Thus, the cysteine residues in the ECL2 of the $A_{2 B}$ receptor not involved in stabilization of the receptor structure may have other functions.

\section{Keywords}




\section{Introduction}

Adenosine $A_{2 B}$ receptors belong to the large group of purinergic $G$ protein-coupled receptors (GPCRs), which comprise P2 (P2Y and P2X, nucleotide-activated ) and P1 (adenosine) receptors [1]. Brunschweiger and Müller [2] proposed to add P0 (adenine) receptors as a third class to the group of purinergic receptors. The P1 or adenosine receptor (AR) family consists of four subtypes, $A_{1}, A_{2 A}, A_{2 B}$ and $A_{3}[3] . A_{1}$ and $A_{3}$ receptors are coupled to $G_{i}$ type $G$ proteins, leading to the inhibition of the adenylate cyclase upon receptor activation, while $A_{2 A}$ and $A_{2 B}$ receptors are mainly coupled to $G_{s}$ proteins resulting in an increase in intracellular cAMP concentrations via stimulation of adenylate cyclase [4]. In several cell systems, such as HEK-293 and HMC-1 mast cells $A_{2 B}$ receptors are additionally coupled to phospholipase $C$ via $G_{q}$ proteins, and are thereby linked to intracellular $\mathrm{Ca}^{2+}$ release [5-6]. In the human leukemia cell line Jurkat $\mathrm{T}, \mathrm{A}_{2 \mathrm{~B}}$-mediated calcium mobilization independent of inositol-1,4,5-trisphosphate was observed [7]. Coupling of the $A_{2 B}$ receptor to the MAPK cascade via ERK1/2 has been described for recombinant $\mathrm{CHO}$ cells overexpressing human $\mathrm{A}_{2 \mathrm{~B}}$ receptors and for mast cells, showing an involvement in proliferation, differentiation and apoptosis $[4,8]$.

Furthermore a link of $A_{2 B}$ receptor signaling to the arachidonic acid signal transduction pathway via phospholipase A and cyclooxygenase activation leading to vasoconstriction in smooth muscle cells has been described [9]. 
Among the four AR subtypes $A_{2 B}$ has been the least well characterized receptor, mainly due to the lack of suitable, specific ligands [10]. Meanwhile highly selective $A_{2 B}$ antagonists have been developed and an $\mathrm{A}_{2 \mathrm{~B}}$-Specific antagonist radioligand, $\left[{ }^{3} \mathrm{H}\right] \mathrm{PSB}-$ 603 (for structure see figure 1), with high potency and specificity across species, including rodents and humans, has recently become available [11]. As for agonists, besides the nucleoside derivative NECA [12], which is non-selective, and related adenosine derivatives, the first highly selective $A_{2 B}$ agonist BAY60-6583 [13], a nonnucleosidic compound, has been developed (structures are shown in supplemental figure 1).

In many tissues, $A_{2 B}$ receptors are considered low affinity receptors with typically low expression levels [14]. Therefore, adenosine concentrations typically have to reach micromolecular levels to activate natively expressed $A_{2 B}$ receptors, which occurs under pathological conditions, such as hypoxia, ischemia, inflammation or massive cell death [15-16]. While their distribution is ubiquitous, $A_{2 B}$ receptors are found at higher densities mainly in the large intestine, in mast cells, hematopoietic cells, and in the brain, mainly in astrocytes [6, 14, 17-18]. Upregulation has been found in several cancer cell lines [19]. $A_{2 B}$ receptors are thought to be involved in a number of diseases and the first antagonist is now being evaluated in clinical trials for the treatment of asthma and chronic obstructive pulmonary disease [10]. Other potential indications include secretory diarrhea associated with inflammation, Alzheimer's disease, inflammatory diseases, pain, cancer, type II diabetes, and diabetic retinopathy [20]. Thus, $A_{2 B}$ receptors represent important new drug targets.

To fully understand interactions of the human $A_{2 B}$ receptor with its ligands, agonists and antagonists, it is of major importance to gain knowledge about the structure of the 
receptor, the amino acid residues involved in ligand binding, and to determine the receptor's 3D structure, which in turn can then be used for the development of new ligands [21-22]. Except for a few mutagenesis studies [16, 23-25] and homology models [26-28], the most recent one based on the X-ray structure of the closely related $A_{2 A}$ receptor [29], not much structural information about the $A_{2 B}$ receptor is available.

A common feature of most GPCRs is the existence of a highly conserved disulfide bond between C3.25 (Ballesteros Weinstein nomenclature [30]) at the extracellular site of transmembrane domain 3 (TMD3) and cysteine residue C45.50 [31] in the extracellular loop 2 (ECL2) located between TMD4 and TMD5 [26-27, 32]. Recently de Graaf et al. [31] undertook a molecular modeling project and aligned ECL2 sequences of 365 human GPCRs. More than $92 \%$ of the investigated receptors showed the conserved disulfide bond.

The $A_{2 B}$ receptor possesses the longest ECL2 of all four adenosine receptor subtypes, with four cysteine residues - the highest number found in any GPCR - of which three (C154, C167, C171) are homologous to the three $(\mathrm{C} 146, \mathrm{C159}, \mathrm{C} 166)$ found in the $\mathrm{A}_{2 \mathrm{~A}}$ receptor (see figures 1 and 2). Those four cysteine residues are not conserved in the known mammalian $A_{2 B}$ receptor orthologs. Therefore, the goal of the present study was to investigate the role of the cysteine residues in the cysteine-rich ECL2 of the $A_{2 B}$ receptor with respect to disulfide bond formation, ligand binding, and receptor activation.

\section{insert figure 1 here}

\section{Material and Methods}


All chemicals were obtained from Roth (Karlsruhe, Germany) or Applichem (Darmstadt, Germany) unless otherwise noted. Radioligands were obtained from Quotient Bioresearch (Cardiff, UK).

\subsection{Alignments of extracellular loops, prediction of disulfide bonds and loop simulation}

Alignments of extracellular loops 1 and 2 of the human $A_{2 A}$ and $A_{2 B}$ receptors were performed using Clustal W2 [33]. Similarity was determined using EMBOSS [34]. Prediction of $\mathrm{N}$-glycosylation was done with NetNGlyc 1.0 from the CBS prediction servers [35]. The topology was illustrated using TOPO2 [36]. Modeling of the nonconserved part of the extracellular loop 2 of the adenosine $A_{2 B}$ receptor was performed with the ModLoop modeling algorithm based on global optimization of conformational energy [37]. In all models, residues in the transmembrane domains and the intracellular loops were restrained by harmonic force to their reference position during simulation; only residues of ECL1 and ECL2 were allowed to move. Loop conformations emerging from this procedure were minimized stepwise with respect to the force field energy by using the Amber package to obtain a low energy conformation [38]. Then the annealing molecular dynamics (MD) was used to optimize the accommodation of ECL1 and ECL2, where the loop atoms were heated from $100 \mathrm{~K}$ to $450 \mathrm{~K}$ and cooled to $100 \mathrm{~K}$ over a period of $1.6 \mathrm{~ns}$. The MD simulations were performed accordingly, restraints with a force constant of $0.5 \mathrm{Kcal} / \mathrm{mol} . \AA^{2}$ were applied to TMDs for $400 \mathrm{ps}$ : heated from $100 \mathrm{~K}$ to 450 $\mathrm{K}$ and $1.2 \mathrm{~ns}$ : then cooled from $450 \mathrm{~K}$ to $100 \mathrm{~K}$. The time step of the simulations was 2.0 fs with a cutoff of $10 \AA$ for the non-bonded interactions. The geometrical parameters of 
the created models were evaluated and compared with the crystal structure of the $A_{2 A}$ receptor using PROCHECK and PROSAII [39-40].

\subsection{Cell culture}

GP+envAM12 packaging cells (ATCC CRL-9641) were cultured at $37^{\circ} \mathrm{C}$ and $5 \% \mathrm{CO}_{2}$ in Dulbecco's modified Eagle medium (DMEM; Invitrogen, Darmstadt, Germany), containing 10\% FCS, $100 \mathrm{U} / \mathrm{ml}$ penicillin G, $100 \mu \mathrm{g} / \mathrm{ml}$ streptomycin, $1 \%$ ultraglutamine, $200 \mu \mathrm{g} / \mathrm{ml}$ hygromycin B, $15 \mu \mathrm{g} / \mathrm{ml}$ hypoxanthine, $250 \mu \mathrm{g} / \mathrm{ml}$ xanthine and $25 \mu \mathrm{g} / \mathrm{ml}$ mycophenolic acid. Chinese hamster ovary $(\mathrm{CHO})$ cells were maintained in DMEM-F12 medium (Invitrogen, Darmstadt, Germany) with 10\% FCS, $100 \mathrm{U} / \mathrm{ml}$ penicillin G, 100 $\mu \mathrm{g} / \mathrm{ml}$ streptomycin and $1 \%$ ultraglutamine under the same conditions. All supplements were from Invitrogen (Darmstadt, Germany), and antibiotics were from Calbiochem (Merck, Darmstadt, Germany).

\subsection{Site-Directed Mutagenesis}

The coding sequence for the human adenosine $A_{2 B}$ receptor was cloned into the plasmid vector pUC19. Point mutations leading to the desired amino acid exchanges were introduced through site-directed mutagenesis using whole plasmid recombination PCR. Complementary oligonucleotide primers were designed containing the corresponding mutations. Therein, each mismatched base is flanked by 12-19 nucleotides at the 3' and 5' end of the primer. The PCR reaction mixture contained $20 \mathrm{ng}$ of template DNA, 15 pmol of each primer, $10 \mathrm{mM}$ dNTPs, $1 \times$ Thermopol reaction buffer and $1 \mathrm{U} \mathrm{Vent}_{\mathrm{R}}$ 


\subsection{Retroviral transfection and membrane preparation}

$\mathrm{CHO}$ cells were stably transfected using a retroviral transfection system as described before [11]. After one week the G418 concentration which is used for the selection was reduced to $200 \mu \mathrm{g} / \mathrm{ml}$. For membrane preparations several dishes of stably transfected $\mathrm{CHO}$ cells were grown to confluence, and then cells were washed and scraped off using 50 mM Tris- $\mathrm{HCl}, \mathrm{pH} 7.4$, containing 2 mM EDTA. After homogenization the cell suspension was centrifuged for $10 \mathrm{~min}$ at $1000 \times \mathrm{g}$ and $4^{\circ} \mathrm{C}$. The low speed supernatant was then centrifuged at $48,000 \times \mathrm{g}$ and $4^{\circ} \mathrm{C}$ for $1 \mathrm{~h}$. Membrane pellets were resuspended in $50 \mathrm{mM}$ Tris- $\mathrm{HCl}, \mathrm{pH} 7.4$, and centrifugation was repeated under the same conditions. Membranes were aliquoted and stored at $-80^{\circ} \mathrm{C}$ until further use. The 
protein concentration of the membrane preparation was determined using the method described by Lowry et al. [41].

\subsection{Cell Surface ELISA}

The cell surface expression of wt and mutant receptors, stably expressed in $\mathrm{CHO}$ cells was determined using ELISA as previously described [42]. In brief, cells were seeded into 24 well plates $24 \mathrm{~h}$ before the assay. Cells were washed with PBS and blocked for 5 min with PBS/1 \% BSA. HA antibody (Covance, Munich, Germany) was diluted 1:1000 in DMEM, 1 \% BSA, $10 \mathrm{mM}$ Hepes, $\mathrm{pH} 7.0,1 \mathrm{mM} \mathrm{CaCl}_{2}$ and added to the cells for $1 \mathrm{~h}$ at room temperature. After washing (3x PBS, 5 min each) cells were fixed with $4 \%$ paraformaldehyde in PBS, washed again and blocked for $10 \mathrm{~min}$. The peroxidasecoupled secondary antibody (goat anti mouse, Sigma, Munich, Germany) was diluted $1: 2500$ in PBS/1 \% BSA and added to the cells for $1 \mathrm{~h}$ at room temperature, after which cells were washed again $4 \times$ with PBS. $300 \mu$ l prewarmed ABTS substrate (Thermo scientific Pierce, Rockford, USA) was added and cells were incubated for $50 \mathrm{~min} .170 \mu \mathrm{l}$ of the substrate were transferred to 96 -well plates and absorption was measured at 405 $\mathrm{nm}$ using fresh substrate as a reference. Experiments were performed in two to six independent experiments, each in triplicates.

\subsection{Radioligand Binding Experiments}

Competition experiments were performed using the high affinity antagonist radioligand $\left[{ }^{3} \mathrm{H}\right] \mathrm{PSB}-603$ [11]. The wild-type receptor (wt) and the mutants C78S, C166S, C167S, 
and C171S were analyzed in a final volume of $500 \mu \mathrm{l}$. The vials contained $25 \mu \mathrm{l}$ of the test compound dissolved in 50\% DMSO / 50\% Tris- $\mathrm{HCl}(50 \mathrm{mM}, \mathrm{pH} 7.4), 275 \mu \mathrm{l}$ of 50 $\mathrm{mM}$ Tris- $\mathrm{HCl}$ buffer $(\mathrm{pH} 7.4), 100 \mu \mathrm{l}$ of radioligand solution in the same buffer (final

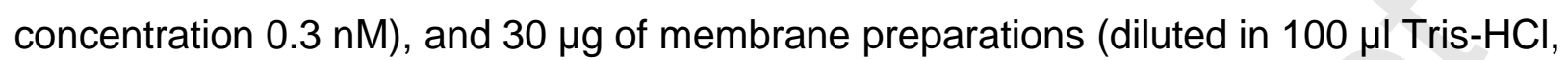
$\mathrm{pH}$ 7.4) which had been preincubated with ADA ( $2 \mathrm{U} / \mathrm{ml})$ for $20 \mathrm{~min}$. The mutants $\mathrm{C} 154 \mathrm{~S}$ and C166S-C167S were analyzed in radioligand binding assays in a final volume of 200 $\mu \mathrm{l}$ containing $50 \mu \mathrm{l}$ of test compound diluted in 10\% DMSO / 90\% Tris- $\mathrm{HCl}(50 \mathrm{mM}, \mathrm{pH}$ 7.4), $50 \mu$ radioligand diluted in Tris- $\mathrm{HCl}$ buffer $(50 \mathrm{mM}, \mathrm{pH} 7.4$, final concentration of the radioligand $0.3 \mathrm{nM}$ ) and $50 \mu \mathrm{g}$ of membrane preparations, diluted in $100 \mu$ buffer, pretreated with ADA $(2 \mathrm{U} / \mathrm{ml}) 20$ min before use. Total binding was determined in the absence of test compound; nonspecific binding was measured in the presence of $10 \mu \mathrm{M}$ 8-cyclopentyl-1,3-dipropylxanthine (DPCPX). After $75 \mathrm{~min}$ at room temperature samples were harvested by filtration through GF/B glass fiber filters. Filters were washed with icecold buffer containing $50 \mathrm{mM}$ Tris- $\mathrm{HCl}(\mathrm{pH} 7.4)$ and $0.1 \%$ bovine serum albumin (BSA), and subsequently transferred into scintillation vials. The liquid scintillation counting of the filters started after $9 \mathrm{~h}$ of pre-incubation in $2.5 \mathrm{ml}$ of scintillation cocktail (Lumag AG, Basel) in order to allow the radioligand to diffuse into the scintillation cocktail. Three independent experiments were performed each in triplicates. If the sample volume for incubation was reduced to $200 \mu$ depletion occurred due to the high affinity and low concentration of the radioligand $\left[{ }^{3} \mathrm{H}\right] \mathrm{PSB}-603$, which means that the free ligand concentration in the solution was actually lower than the concentration added [43].

\subsection{Saturation assays}


Saturation experiments were performed in duplicates as described in paragraph 2.6 with radioligand concentrations ranging from $0.05-1.6 \mathrm{nM}$ in $50 \mathrm{mM}$ Tris- $\mathrm{HCl}(\mathrm{pH} 7.4)$.

\subsection{Determination of intracellular cAMP accumulation}

Stably transfected $\mathrm{CHO}$ cells expressing the wild-type or mutant receptors were plated onto 24 well plates at a density of 200,000 cells per well. After $24 \mathrm{~h}$ the medium was removed and the cells were washed with $500 \mu$ of $37^{\circ} \mathrm{C}$ warm Hank's Balanced Salt Solution (HBSS; 20 mM HEPES, 135 mM NaCl, 5.5 mM glucose, 5.4 mM KCl, 4.2 mM $\mathrm{NaHCO}_{3}, 1.25 \mathrm{mM} \mathrm{CaCl}_{2}, 1 \mathrm{mM} \mathrm{MgCl}, 0.8 \mathrm{mM} \mathrm{MgSO}_{4}, 0.44 \mathrm{mM} \mathrm{KH}_{2} \mathrm{PO}_{4}$ and $0.34 \mathrm{mM}$ $\mathrm{Na}_{2} \mathrm{HPO}_{4}$, pH adjusted to 7.3) containing $1 \mathrm{U} / \mathrm{ml}$ of adenosine deaminase (ADA, Sigma). The cells were then incubated in $300 \mu$ of $\mathrm{HBSS}$ with ADA at $37^{\circ} \mathrm{C}$ and $5 \% \mathrm{CO}_{2}$ for 2 h. Then, $100 \mu$ l of the phosphodiesterase inhibitor Ro20-1724 (Hoffmann La Roche, Grenzach, Germany; final concentration $40 \mu \mathrm{M})$ were added to each well and the cells were incubated for $15 \mathrm{~min}$ at $37^{\circ} \mathrm{C}$ and $5 \% \mathrm{CO}_{2}$. Then $100 \mu$ of various dilutions of the agonists 5'-N-ethylcarboxamidoadenosine (NECA; Sigma, Munich, Germany), or BAY60-6583 (Bayer Schering Pharma), respectively in HBSS containing 5 \% DMSO were added in triplicates (final DMSO concentration $0.5 \%$ ). After 15 min of incubation at $37^{\circ} \mathrm{C}$ and $5 \% \mathrm{CO}_{2}$ the supernatant was removed and $500 \mu \mathrm{l}$ of $90^{\circ} \mathrm{C}$ hot lysis buffer consisting of $4 \mathrm{mM}$ EDTA and $0.01 \%$ Triton $\mathrm{X}-100$ with the $\mathrm{pH}$ adjusted to 7.3 were added. After one hour of mixing on ice, cAMP amounts of the lysates were determined by competitive radioligand binding experiments [44]. Competition experiments were performed in a final volume of $120 \mu$ l containing $50 \mu$ l of cell lysates, $30 \mu \mathrm{l}$ of $\left[{ }^{3} \mathrm{H}\right] \mathrm{cAMP}$ radioligand solution in lysis buffer (final concentration $3 \mathrm{nM}$ ) and $40 \mu$ of cAMP binding 


\subsection{Experiments with DTT pretreatment}

The effect of dithiothreitol (DTT) on receptor function was investigated by measuring NECA-induced cAMP accumulation as described in 2.8, except that $\mathrm{CHO}$ cells, stably expressing the human $A_{2 B}$ receptor, were preincubated with $10 \mathrm{mM}$ DTT for $2 \mathrm{~h}$ at $37^{\circ} \mathrm{C}$.

\section{Results}

\subsection{Comparison of extracellular loops 1 and 2 of $A_{2 A}$ and $A_{2 B}$ receptors}


The $A_{2 A}$ receptor is the adenosine receptor subtype, which is most closely related to the $A_{2 B}$ receptor. Sequence analysis of the human $A_{2 A}$ and $A_{2 B}$ receptors show an overall identity of $58 \%$ and a similarity of $73 \%$. The most conserved residues are found within the transmembrane domains. By comparing the extracellular loops 1 and 2, which show $44 \%$ and $34 \%$ identity, and $56 \%$ and $46 \%$ similarity, respectively, one can find extremely high degrees of homology when comparing the residues close to the cysteine residues $\mathrm{C} 71, \mathrm{C} 77, \mathrm{C} 166$ in the $\mathrm{A}_{2 \mathrm{~A}}$ receptor and the corresponding residues $\mathrm{C} 72, \mathrm{C} 78$, C171 in the $A_{2 B}$ receptor (see figure 2). The residues adjacent to those cysteine residues are identical or at least similar in $A_{2 A}$ and $A_{2 B}$ receptors in both extracellular loops. The region between the conserved cysteine $C 45.50$ ( $C 166$ in $A_{2 A}, C 171$ in $\left.A_{2 B}\right)$ in ECL2 and TMD5 is even $86 \%$ identical and $100 \%$ similar, providing evolutionary evidence for the importance of that partial structure. The ECL2 of both receptors contain potential N-glycosylation sites between the highly similar stretch between the conserved cysteine residues $C 146$ and $C 159$ in the $A_{2 A}$ receptor, and $C 154$ and $C 167$ in the $A_{2 B}$ receptor, respectively. The $A_{2 B}$ receptor contains a second potential $\mathrm{N}$-glycosylation site at N153, where $\mathrm{C} 154$ is part of the sequon. The $A_{2 B}$ receptor has a 7-amino acid insertion at the site close to TMD4 and a 3-amino acid gap between the conserved cysteine residues $\mathrm{C} 167$ and $\mathrm{C} 171$, moving those cysteine residues and the adjacent glycosylation site closer together as compared to the $A_{2 A}$ receptor. The crystal structure of the $A_{2 A}$ receptor [45] shows two $\beta$-sheets in ECL1 and ECL2 both being in an antiparallel conformation. According to the refined computer model based on the published model [29], the $A_{2 B}$ receptor can also form one $\beta$-sheet in each of the extracellular loops 1 and 2, which appear to be close enough together to be able to form 


\subsection{Disulfide bond prediction}

For predicting disulfide bonds in the ECL2 of the $A_{2 B}$ receptor, models of the $A_{2 A}$ receptor based on the published X-ray structure were initially generated for testing the procedure. One of the generated models $\left(\mathrm{m} 1 \mathrm{~A}_{2 \mathrm{~A}}\right)$ contained the highly conserved disulfide bond between C3.25 and C45.50, corresponding to C77 (TMD3) and C166 (ECL2), while a second model (m2 $\mathrm{A}_{2 \mathrm{~A}}$ ) contained all four possible bonds (C77-C166, C74-C146, C71-C159, and C259-C262), which were observed in the X-ray structure of the $A_{2 A}$ receptor [45]. Table 1 lists the fixed disulfide bonds and the results of the analyses used to evaluate the goodness of the models obtained by several programs, such as PROCHECK (Psi/Phi angles), PROSAll (Z-scores) and root mean square distances (RMSD), both in comparison to the $A_{2 A} X$-ray structure and the initial $A_{2 A}$ or $A_{2 B}$ model. The psi/phi angles, which are obtained by PROCHECK are determined using a Ramachandran plot, which is a way to visualize the dihedral angles (psi against phi) of amino acid residues in protein structures, where psi is the angle between carbon and carbonyl and phi the angle between carbon and nitrogen. Lower values indicate better quality of the model. Z-scores, obtained by PROSAll, indicate the overall model quality; 
its value is displayed in a plot which shows the local model quality by plotting energies as a function of the amino acid sequence position. In general, positive values correspond to problematic parts of the input structure, negative values indicate good quality. RMSD values are a useful way to compare two models either of the same structure or two closely related structures, such as the crystal structure of the $A_{2 A}$ receptor and the model of the the $A_{2 B}$ receptor. The values reflect the average distances between the backbones of the proteins. Lower values indicate good accordance between two models or structures. Model 2, containing all four disulfide bonds, observed in the $A_{2 A}$ crystal structure $\left(m 2 A_{2 A}\right)$ led to better values and scores and was therefore chosen as reference for the predictions of disulfide bonds in the $A_{2 B}$ receptor (see table 1). Four different $A_{2 B}$ receptor models with combinations of fixed disulfide bonds were compared to $m 2 A_{2 A}$ and the initial $A_{2 B}$ model without any disulfide bonds [29]. Figure $3 \mathrm{~A}$ shows the positions of the cysteine residues potentially involved in disulfide bond formation in the initial $A_{2 B}$ model before loop simulation, as well as the two asparagine residues, which could be glycosylated. According to the Z-score, model 2 ( $m 2 \mathrm{~A}_{2 \mathrm{~B}}$ ) containing two disulfide bonds, $\mathrm{C} 78-\mathrm{C} 171$ and $\mathrm{C} 72-\mathrm{C} 167$, would be the preferred model, since positive values correspond to problematic parts of the input structure while negative values indicate high quality. According to all other parameters determined, model 1 ( $\mathrm{m}_{1} \mathrm{~A}_{2 \mathrm{~B}}$ ), containing only the highly conserved disulfide bond between TMD3 and ECL2, C78-C171, is the most likely prediction. The more significant analysis of the loop motions during simulation allows a comparison of the fluctuation profiles along the sequences of all models (see figure 4). Since all protein parts except for ECL1 and ECL2 have been restrained to their initial position during simulation, only motions in the ECL1 and ECL2 segments are observed. It was found that $m 1 A_{2 B}$ and $m 4 A_{2 B}$, i.e. the 
model with the lowest number of disulfide bonds and the one with the highest number of disulfide bonds, produce B-factor profiles very similar to the one of the tightly constrained $\mathrm{m} 2 \mathrm{~A}_{2 \mathrm{~A}}$ model with four disulfide bonds. B-factors indicate the true static or dynamic mobility of an atom; it can also indicate errors in model building (reflected in higher values, corresponding to the peaks in figure 4). However, introducing a disulfide bond between $\mathrm{C} 72-\mathrm{C} 166$ and $\mathrm{C} 72-\mathrm{C} 167$, respectively, apparently leads to a structural destabilization. The analysis of average B-factors shows a preference for models 1 and 4 (see figure 4). ECL2 contains two potential glycosylation sites, N153 and N163, both close to cysteine residues. In model 1 and model 2 both sites are accessible for glycosylation. As shown in figure 3B, in model 1 the two extracellular loops 1 and 2 are held together by two antiparallel $\beta$-sheets, while the loops in model 2 are connected by a second disulfide bond between C72 and C167. The $\beta$-sheet in ECL1 appears to be very stable, while the $\beta$-sheet in ECL2 was less stable during the simulation process. With the $\beta$-sheet present in ECL2, C72 and C167 are about $10 \AA$ apart, making it very unlikely to form a disulfide bond. Model 3, having a second disulfide bond between $\mathrm{C} 72$ and $\mathrm{C} 166$, is less likely than models 1 and 2 according to the values and scores (see table 1), and model 4 can be excluded because of unfavorable values (see table 1), in addition, both potential glycosylation sites are not exposed to the solvent, but are facing the helices. Thus, molecular modeling studies indicate that the $A_{2 B}$ receptor might contain a second disulfide bond (C72-C167) next to the highly conserved bond between $\mathrm{C} 78$ and $\mathrm{C} 171$ (model 2).

insert figures 3 and 4, and table 1 here 


\title{
3.3. Effects of DTT pretreatment on $A_{2 B}$ receptor activity
}

\begin{abstract}
A first experimental indication that disulfide bond formation is essential for $A_{2 B}$ receptor function was obtained by preincubating $\mathrm{CHO}$ cells stably expressing human $\mathrm{A}_{2 \mathrm{~B}}$ receptors with DTT followed by NECA-induced cAMP accumulation assays. As shown in figure 5 the curve for the agonist NECA was shifted to the right by 74-fold compared to $A_{2 B}$ receptor activity without DTT pretreatment ( $\mathrm{CC}_{50}$ values: $2720 \mathrm{nM}$ vs. $\left.36.6 \mathrm{nM}\right)$.
\end{abstract}

\section{insert figure 5 here}

\subsection{Comparison of $A_{2 B}$ wild-type receptors with and without $\mathrm{HA}$ tag}

As a next step we planned to exchange each of the cysteine residues in ECL2 of the human $\mathrm{A}_{2 \mathrm{~B}}$ receptor for serine. For comparison of the mutant receptors with the wildtype receptor it was essential to determine their cell surface expression by ELISA. Therefore tagging of the receptors was required. Receptors were HA-tagged at the $\mathrm{N}$ terminus, which had been shown not to interfere with ligand binding and function for several other GPCRs [42]. Potential interference of the tag at the $A_{2 B} A R$ was investigated in radioligand binding as well as in functional assays. As shown in figure 6 binding of ligands to the $\mathrm{HA}$-tagged $\mathrm{A}_{2 \mathrm{~B}}$ receptor was not altered in comparison to the wt receptor. $\mathrm{K}_{\mathrm{D}}$ values (untagged wt: $0.403 \pm 0.188 \mathrm{nM}, \mathrm{HA}$-tagged wt: $0.473 \pm 0.170 \mathrm{nM}$ ) calculated from saturation experiments were not significantly different (see figure 7). Although $B_{\max }$ values (untagged wt: $502 \pm 57 \mathrm{fmol} / \mathrm{mg}$, HA-tagged wt: $283 \pm 37 \mathrm{fmol} / \mathrm{mg}$ ) 
differed slightly, expression of both, tagged and untagged receptors was in the same range. Neither for the antagonist PSB-603 nor for the agonists NECA and BAY60-6583 significant differences of $\mathrm{K}_{\mathrm{i}}$ values determined in radioligand binding studies could be found (see supplemental table 1 and figure 6 ). When comparing the functionality of the HA-tagged receptors to the wild-type receptors no significant differences could be detected either. Figure 8 shows the results of cAMP accumulation experiments using whole cells with two structurally different agonists, NECA (figure 8A) and BAY60-6583 (figure 8B and supplemental table 1). For NECA, $\mathrm{EC}_{50}$ values of $26.9 \pm 4.5 \mathrm{nM}$ (untagged) and $36.6 \pm 4.8 \mathrm{nM}$ (tagged) were determined, and for BAY60-6583 $37.5 \pm$ $12.3 \mathrm{nM}$ and $42.4 \pm 4.4 \mathrm{nM}$, respectively.

\title{
insert figures 6-8 here
}

\subsection{Characterization of mutant receptors}

\begin{abstract}
All receptor cDNA sequences were subcloned into the retroviral expression vector pLXSN and stably expressing $\mathrm{CHO}$ cells were generated. Cysteine residues (C78, C154, C166, C167, and C171) which were replaced by serine via site directed mutagenesis are highlighted in a topology model of the $A_{2 B}$ receptor (figure 1). Cell surface expression levels for all mutants were determined by ELISA and compared to that of the wt receptor (see figure 9)
\end{abstract}

insert figure 9 here 
Cysteine mutants were analyzed in radioligand binding studies using the antagonist radioligand $\left[{ }^{3} \mathrm{H}\right] \mathrm{PSB}-603$ versus unlabeled $\mathrm{PSB}-603$ as well as versus the agonist NECA (see supplemental figure 2). All mutants were compared to the wt receptor. Binding of [ $\left.{ }^{3} \mathrm{H}\right] \mathrm{PSB}-603$ (0.3 nM) to C78S and C171S mutants was completely abolished; therefore no competition binding curves could be determined. In contrast, the mutants C166S, C167S, and the double mutant C166S-C167S showed similar affinity for PSB-603 and NECA as the wt receptor. A difference was, however, seen with C154S: it exhibited a significantly, 8-fold increased $\mathrm{IC}_{50}$ value for PSB-603, while no significant difference was observed for the agonist NECA (table 2).

\section{insert table 2 here}

NECA-induced cAMP accumulation was examined using cells expressing the generated mutants (figure 10A). In contrast to the mutants C166S, C167S, and C166S-C167S, which showed $\mathrm{EC}_{50}$ values that were not significantly different from that determined at the wt, the mutants C78S, C154S, and C171S showed significantly increased $\mathrm{EC}_{50}$ values compared to the wild-type receptor (table 3 ). While the $\mathrm{EC}_{50}$ value for the mutant C154S was moderately (2.7-fold) increased, the dose-response curves for the mutants C78S and C171S were dramatically shifted to the right, resulting in an almost 7000-fold increase in the $\mathrm{EC}_{50}$ value in the mutant C78S (397 $000 \pm 7700 \mathrm{nM}$ ) compared to that of the wild-type receptor $(58.1 \pm 1.2 \mathrm{nM})$, and a similarly large increase for the mutant $\mathrm{C} 171 \mathrm{~S}$ (to $256000 \pm 28900 \mathrm{nM}$ ). At the mutated receptors $\mathrm{C} 78 \mathrm{~S}$ and $\mathrm{C} 171 \mathrm{~S}$ the $\mathrm{EC}_{50}$ of the non-nucleosidic agonist BAY60-6583 was also dramatically increased, similarly as observed for NECA. Due to the limited solubility of BAY60-6583 full concentration- 


\section{Discussion}

The extracellular loops ECL1 [25], ECL2 [31], and ECL3 [42] of GPCRs belonging to the rhodopsin family have been found to contribute considerably to receptor function [46]. However, extracellular loops differ widely in length, sequence, and structure between different GPCRs and even between closely related receptor subtypes [31]. Cysteine residues and disulfide bonds present in the extracellular domains of GPCRs have been reported to play important roles in ligand binding, receptor stability, and receptor function $[32,47-48]$. The adenosine $A_{2 B}$ receptor contains the highest number of cysteine residues in the ECL2 of all mammalian GPCRs (C154, C166, C167, C171) [31]. Therefore we were interested in studying the role of these cysteine residues and their potential involvement in the formation of disulfide bonds.

Most rhodopsin-like GPCRs contain a disulfide bond between the highly conserved cysteine residue $C 3.25$ corresponding to $C 78$ in the $A_{2 B}$ receptor, which is located in TMD3 and the conserved cysteine residue C45.50 in the second extracellular loop (C171 in $A_{2 B}$ ). For several GPCRs this disulfide bond has been shown to play a critical role for correct receptor conformation and activation [47]. The ECL2 is especially known to be involved in antagonist binding, which could experimentally be shown for several 
receptors, e.g. the dopamine D2 receptor [49] and the adenosine $A_{3}$ receptor [50]. Compared to the ECL2 of the other adenosine receptor subtypes, the ECL2 of the $A_{2 B}$ receptor shows several differences: (i) the loop is between 4 and 10 amino acids longer; (ii) ECL2 contains the most cysteine residues, four compared to three in $A_{2 A}$, all of which are involved in disulfide bonds according to the $A_{2 A}$ receptor crystal structure [45], and only one in $A_{1}$ and $A_{3}$ receptors; (iii) the loop has two potential $\mathrm{N}$-glycosylation sites compared to only one in each of the other adenosine receptor subtypes. The highest conservation of the ECL2 is found in the part of ECL2 which is close to TMD5. The sequence upstream of the conserved cysteine is shorter than the corresponding sequence in bovine rhodopsin, 9 amino acids compared to 14 amino acids [31]. The conserved area between C45.50 and TMD5 is also very close to the binding pocket and stabilized by the essential disulfide bond between TMD3 and ECL2, and therefore probably not very flexible, while the less conserved area closer to TMD4 is highly flexible and might be involved in ligand selection, or function as a cap in analogy to the gated entrance pores described for several GPCRs $[31,51]$. The $\beta$-sheet just upstream of the conserved disulfide bond further stabilizes this end of ECL2. In the X-ray structure of the $A_{2 A}$ receptor a second disulfide bond is holding the $\beta$-sheet in place making this area even less flexible. This part of the loop could therefore be at least partly responsible for the high affinity of the $A_{2 A}$ receptor for adenosine and related agonists by stabilizing the active conformation. The loop in the $A_{2 A}$ receptor is shorter, and thus, the entrance to the binding pocket is probably open and more accessible to the ligands. This hypothesis may also explain why $A_{2 B}$ receptors typically show lower affinity for adenosine and adenosine derivatives (agonists) than $A_{2 A}$ receptors, since the longer $E C L 2$ of the $A_{2 B}$ 
receptors may in some cases partially block the entrance to the binding pocket. The ECL2 might be involved in transient, low-affinity ligand binding. Especially binding of large ligands with long substituents extending to the receptor surface may interfere with ECL2 movement or "gate closing". This might explain the effect of the C154S mutant on PSB-603 binding. ECL2 movement may also be required for proper receptor activation. In accordance with this hypothesis is the finding of Bokoch et al. describing ligandinduced conformational changes of the extracellular surface of the $\beta 2$ adrenergic receptor $\left(\beta_{2} A R\right)$, especially involving ECL2 and ECL3 [51]. They also describe the formation of a structured cap which covers the opening of the binding pocket once a ligand is bound, involving ECL2 and a salt bridge between an aspartate residue and a lysine residue connecting ECL2 and ECL3. The $A_{2 B}$ receptor exhibits those amino acids in equivalent positions (K269 at the transition from ECL3 to TMD7 corresponding to Lys305 in the $\beta_{2} A R$ and Asp159 in ECL2 corresponding to Asp192 in the $\beta_{2} A R$, rendering a similar mechanism probable [51].

\footnotetext{
Dithiothreitol (DTT), a disulfide-reducing agent, which is commonly used to investigate the importance of disulfide bonds in proteins, was applied to examine whether the $A_{2 B}$ receptor possesses essential disulfide bonds necessary for receptor function [42]. As shown in figure 5 a dramatic decrease in receptor function could be observed which has also been shown for some other GPCRs containing the conserved disulfide bond connecting TMD3 and ECL2 $[42,45]$. These results clearly show that at least one disulfide bond, susceptible to DTT reduction and, thus, presumably exposed to the surface of the cell membrane, is important for receptor function.
} 
Subsequently each cysteine residue of the $A_{2 B}$ receptor located in the ECL2, as well as C78 in the external half of TMD3 was individually replaced by the sterically and electronically similar serine, which lacks the ability to participate in disulfide bond formation but is still able to form $\mathrm{H}$-bonds, which are even stronger for the $\mathrm{OH}$ group of serine than for the original SH group of its cysteine homologue. Through site-directed mutagenesis DNA constructs coding for the mutations C78S (TMD3), C154S, C166S, C167S, and C171S (ECL2) of the $A_{2 B}$ receptor were generated. In addition, a C166SC167S double mutant was constructed. To obtain comparable $\mathrm{EC}_{50}$ values mutants were compared to cells overexpressing wild-type receptors at the same level. Therefore shifts of $\mathrm{EC}_{50}$ values were due to reduced binding or function and not due to different expression levels. Only two mutants, $\mathrm{C} 78 \mathrm{~S}$ and $\mathrm{C} 171 \mathrm{~S}$ showed somewhat lower expression levels.

As predicted by the $A_{2 B}$ model it could clearly be shown, that C78 in TMD3 and C171 in ECL2 are forming an important disulfide bond. The results obtained in radioligand binding as well as functional studies showed a dramatic decrease in $\mathrm{IC}_{50}$ and $\mathrm{EC}_{50}$ values of several thousand-fold for the mutants C78S and C171S. All other mutants either showed no difference or only moderate changes compared to the wild-type receptor. It is known that disulfide bonds are already formed in the endoplasmic reticulum (ER) and are very often necessary for proper folding and transport to the Golgi apparatus. Therefore mutants without essential disulfide bonds are more prone to degradation than wild-type receptors, further explaining somewhat lower cell surface expression levels $[47,52]$. While $\mathrm{EC}_{50}$ values determined in functional studies may be 
dependent on the receptor expression level, affinities measured in radioligand binding studies are not. The extreme rightward shift of the concentration response curves in functional assays can also not be explained by the somewhat lower expression levels in the mutant receptors, which would be expected to cause only a moderate shift at the most [42]. Thus it can be concluded that the disulfide bond C78-C171 in $A_{2 B}$ receptors is essential for ligand binding and receptor function.

\begin{abstract}
Based on the results of radioligand binding and functional assays as well as loop simulations (figures 4, 9, 10; tables 1-3), model m1 $\mathrm{A}_{2 \mathrm{~B}}$, containing only the conserved disulfide bond between $\mathrm{C} 78$ and $\mathrm{C} 171$, represents the most likely structure. It was shown that this disulfide bond is essential for proper receptor function (figure 10).
\end{abstract} According to our experimental data, all other disulfide bonds that had been predicted or might be formed are less likely. If C72, located in the first extracellular loop, was involved in linking ECL1 and ECL2 via a disulfide bond, similar to the situation found in the $A_{2 A} X$-ray structure [45], and this bond was essential for receptor function, one of the ECL2 cysteine mutants should show different properties than the wild-type receptor. ECL1 and ECL2 are held together by antiparallel $\beta$-sheets as predicted by the model $\mathrm{m} 1$ $A_{2 B}$. Both $\beta$-sheets are also present in the $A_{2 A}$ receptor [45]. Two of the possible cysteine residues proposed to be involved in forming a hypothetical second disulfide bond with C72, namely $\mathrm{C} 166$ and $\mathrm{C} 167$ ( $\mathrm{m}_{2} \mathrm{~A}_{2 \mathrm{~B}}$ and $\mathrm{m} 3 \mathrm{~A}_{2 \mathrm{~B}}$ ), are located adjacent to the putative $\mathrm{N}$-glycosylation site N163. Disulfide bond formation usually prevents glycosylation of nearby glycosylation sites. When a disulfide bond cannot be formed due to mutagenesis of cysteine residues, substitution of normally unused glycosylation sites is common [53]. 
In case $\mathrm{C} 166$ or $\mathrm{C} 167$ would be involved in a second disulfide bond with C72, N163 could be glycosylated in the cysteine mutants C166S, C167S, and C166S-C167S. This glycosylation might then change the conformation of the receptor leading to larger amounts of misfolded protein and to more degradation and, as a consequence, to lower levels of cell surface expression, which was, however, not observed in our mutants (see figure 9). Alternatively, N163-glycosylation could result in changes in ligand binding and/or to altered function of the mutant receptors. However, in both mutants, C166S and C167S as well as in the double mutant C166S-C167S neither changes in expression nor binding and receptor function could be observed. This leads to the conclusion that both, disulfide bond formation as well as glycosylation is unlikely. A further candidate cysteine residue potentially involved in forming a hypothetical second bond with $\mathrm{C} 72$ is $\mathrm{C} 154$. This amino acid residue is the central part of the sequon N-X-S/T for the putative $\mathrm{N}$ glycosylation site N153. If the bond were essential, an effect of the C154S in ligand binding and receptor function were to be expected. If the bond is not formed, glycosylation of $\mathrm{N} 153$ would be likely and should not be affected by the cysteine to serine exchange, since the sequon $\mathrm{N}-\mathrm{X}-\mathrm{S} / \mathrm{T}$ allows any amino acid except for proline in the middle position. Thus, no change in ligand binding and receptor function should be expected in the mutant if no disulfide bond is formed. Interestingly, $A_{2 B}$ receptors from birds and bony fish, which only possess two cysteine residues in the ECL2 show the closely related serine residue at that position. From the evolutionary point of view they have developed independently from the mammalian $A_{2 B}$ receptors because they separated even before the $A_{2 A}$ receptors emerged [54]. The $A_{2 A}$ receptor possesses an asparagine residue adjacent to the cysteine residue corresponding to $\mathrm{C} 154$, but the sequon is lost, probably in favor for gaining more stability of the loops through disulfide 
bonds. Curiously, the mutant C154S showed an 8-fold decrease in affinity for the antagonist PSB-603, while agonist binding was not significantly altered as compared to the wild-type (supplemental figure 2, table 2). Receptor function of the C154S mutant on the other hand was significantly altered depending on the agonist used. The nucleosidic agonist NECA was about three-fold less potent, while the non-nucleosidic agonist BAY60-6583 was slightly more potent at the C154S mutant receptor in comparison with the wild-type receptor.

This leads to the hypothesis that free cysteine residues, especially C154, could play a role in the interaction with specific ligands as it has been described for other GPCRs, e.g. for $\mathrm{P}_{2} \mathrm{Y}_{12}$ [48], the $\beta 2$ adrenergic receptor [55], or the cannabinoid receptor 2 [56]. Thus, free cysteine residues in the extracellular loops of the $A_{2 B}$ receptor may allow for the development of new drugs, especially for inhibiting receptor function.

\begin{abstract}
A possible explanation for the occurrence of the high number of cysteine residues in the ECL2 of the $A_{2 B}$ receptor, which are not involved in disulfide bond formation under native conditions, could be that they are part of a regulatory system, which may, for example, explain the down-regulation of $A_{2 B}$ receptors during oxidative stress. Such an effect has been described for alveolar macrophages from patients with chronic obstructive pulmonary disease [57]. Oxidative stress leads to more oxidizing conditions in the ER lumen, which in turn may lead to disulfide bond formation of non-native bonds, resulting in more misfolded proteins, more degradation and finally to less $A_{2 B}$ receptors at the cell surface. The $A_{2 A}$ receptor, which is upregulated under oxidative stress $[45,57]$ would not be affected, because all four possible disulfide bonds are formed in the functional $A_{2 A}$
\end{abstract}


receptor, at least according to the X-ray structure [45], as well as according to a recent molecular modeling study [58].

The cysteine residues could be involved in controlling/regulating receptor function by forming so-called allosteric disulfide bonds, e.g. by promoting or stabilizing the active or inactive receptor conformation [54]. Since most X-ray structures of GPCRs reported to date represent the inactive, antagonist-bound conformation, it cannot be excluded that one or more cysteine residues might be involved in allosteric disulfide bonds and would either be reduced in the active receptor conformation or could have formed artificially during the crystallization process. Usually allosteric disulfide bonds are controlled by catalytic disulfides of oxidoreductases, which are regulated through changes in the oxidizing environment, e.g. through oxidative stress [54]. The fact that the structurally different ligands - PSB-603, NECA, and BAY60-6583 - resulted in different changes in $\mathrm{IC}_{50^{-}}$or $\mathrm{EC}_{50}$ (decreased or increased values) in the $\mathrm{C} 154 \mathrm{~S}$ mutant as compared to the wild-type receptor indicates that C154 may be directly or indirectly involved in ligand binding. However, this hypothesis cannot be confirmed by our homology model.

Free cysteine residues can also be involved in metal ion complexation, e.g. with $\mathrm{Zn}^{2+}$, $\mathrm{Pb}^{2+}$ or $\mathrm{Hg}^{2+}$. So far, reports about the role of metal ion complexation in the regulation of GPCRs are scarce. Inhibitory effects of $\mathrm{Zn}^{2+}$ on ligand binding at the serotonin receptor 5- $\mathrm{HT}_{1 \mathrm{~A}}$ have been reported; the physiological significance, however, remained unclear [59]. A few other studies also showed allosteric effects of zinc ions on ligand binding at GPCRs (dopamine, metabotropic glutamate and $\beta 2$-adrenergic receptors) with likewise 
unresolved physiological significance [60-61]. For several receptors, involvement of cysteine residues in dimerization has been shown. In these cases, however, cysteine residues were exclusively localized in the transmembrane domains or in intracellular loops [62-63].

In summary, we showed that the conserved disulfide bond between C3.25 in TMD3 and C45.50 in ECL2 is essential for adenosine $A_{2 B}$ receptor ligand binding and function and it also appears to improve transport of the receptors to the plasma membrane.

Furthermore we have strong evidence that all other cysteine residues in the ECL2 are not involved in disulfide bond formation and if they were, that those bonds would not have any effects, neither on ligand binding, nor on receptor function. Only Cys 154 appears to have small, significant effects on ligand binding. Thus, the cysteine residues in the ECL2 of the $A_{2 B}$ receptor may serve very different roles from those of the extracellular cysteine residues in the $A_{2 A}$ receptor.

\title{
Acknowledgements
}

\author{
A.C.S., D.T., and C.E.M. are supported by the state of NRW (NRW International \\ Research Graduate School BIOTECH-PHARMA). T.B. was supported by a stipend \\ provided by the Bischöfliche Studienförderung Cusanuswerk. We would like to thank \\ Susan Jean Johns for upgrading the TOPO2 program to fulfill our needs for more colors \\ in the topology model. We are also grateful to Dr. Thomas Krahn, Bayer Healthcare \\ (Germany) for providing BAY60-6583.
}




\section{References}

[1] Burnstock G. Purine and pyrimidine receptors. Cell Mol Life Sci 2007;64:1471-83.

[2] Brunschweiger A, Müller CE. P2 receptors activated by uracil nucleotides--an update. Curr Med Chem 2006;13:289-312.

[3] Fredholm BB, ljzerman AP, Jacobson KA, Linden J, Müller CE. Nomenclature and Classification of Adenosine Receptors - An update. Pharmacol Rev 2011;63:1-34.

[4] Schulte G, Fredholm BB. Signalling from adenosine receptors to mitogenactivated protein kinases. Cell Signal 2003;15:813-27.

[5] Linden J, Thai T, Figler H, Jin X, Robeva AS. Characterization of human A(2B) adenosine receptors: radioligand binding, western blotting, and coupling to $\mathrm{G}(\mathrm{q})$ in human embryonic kidney 293 cells and HMC-1 mast cells. Mol Pharmacol 1999;56:705-13.

[6] Feoktistov I, Biaggioni I. Adenosine A2B receptors. Pharmacol Rev 1997;49:381402.

[7] Mirabet M, Mallol J, Lluis C, Franco R. Calcium mobilization in Jurkat cells via $A_{2 b}$ adenosine receptors. Br J Pharmacol 1997;122:1075-82.

[8] Pearson G, Robinson F, Beers Gibson T, Xu BE, Karandikar M, Berman K, et al. Mitogen-activated protein (MAP) kinase pathways: regulation and physiological functions. Endocr Rev 2001;22:153-83.

[9] Donoso MV, Lopez R, Miranda R, Briones R, Huidobro-Toro JP. A $2 \mathrm{~B}$ adenosine receptor mediates human chorionic vasoconstriction and signals through arachidonic acid cascade. Am J Physiol Heart Circ Physiol 2005;288:H2439-49.

[10] Müller CE, Jacobson KA. Recent developments in adenosine receptor ligands and their potential as novel drugs. Biochim Biophys Acta 2010; 1808:1290-308.

[11] Borrmann T, Hinz S, Bertarelli DC, Li W, Florin NC, Scheiff AB, et al. 1-alkyl-8(piperazine-1-sulfonyl)phenylxanthines: development and characterization of adenosine $A_{2 B}$ receptor antagonists and a new radioligand with subnanomolar affinity and subtype specificity. J Med Chem 2009;52:3994-4006.

[12] Yan L, Burbiel JC, Maass A, Müller CE. Adenosine receptor agonists: from basic medicinal chemistry to clinical development. Expert Opin Emerg Drugs 2003;8:537-76.

[13] Baraldi PG, Tabrizi MA, Fruttarolo F, Romagnoli R, Preti D. Recent improvements in the development of $\mathrm{A}(2 \mathrm{~B})$ adenosine receptor agonists. Purinergic Signal 2008;4:287-303. Epub 2008 Apr 29.

[14] Fredholm BB. Adenosine, an endogenous distress signal, modulates tissue damage and repair. Cell Death Differ 2007;14:1315-23.

[15] Kong T, Westerman KA, Faigle M, Eltzschig HK, Colgan SP. HIF-dependent induction of adenosine $A_{2 B}$ receptor in hypoxia. FASEB J 2006;20:2242-50.

[16] Beukers MW, van Oppenraaij J, van der Hoorn PP, Blad CC, den Dulk H, Brouwer J, et al. Random mutagenesis of the human adenosine $A_{2 B}$ receptor followed by growth selection in yeast. Identification of constitutively active and gain of function mutations. Mol Pharmacol 2004;65:702-10.

[17] Ryzhov S, Zaynagetdinov R, Goldstein AE, Novitskiy SV, Dikov MM, Blackburn $\mathrm{MR}$, et al. Effect of A2B adenosine receptor gene ablation on proinflammatory adenosine signaling in mast cells. J Immunol 2008;180:7212-20. 
[18] Trincavelli ML, Marroni M, Tuscano D, Ceruti S, Mazzola A, Mitro N, et al. Regulation of $\mathrm{A} 2 \mathrm{~B}$ adenosine receptor functioning by tumour necrosis factor a in human astroglial cells. J Neurochem 2004;91:1180-90.

[19] Ryzhov S, Novitskiy SV, Zaynagetdinov R, Goldstein AE, Carbone DP, Biaggioni I, et al. Host $A(2 B)$ adenosine receptors promote carcinoma growth. Neoplasia 2008;10:987-95.

[20] Volpini R, Costanzi S, Vittori S, Cristalli G, Klotz KN. Medicinal chemistry and pharmacology of A2B adenosine receptors. Curr Top Med Chem 2003;3:427-43.

[21] Pastorin G, Federico S, Paoletta S, Corradino M, Cateni F, Cacciari B, et al. Synthesis and pharmacological characterization of a new series of 5,7 disubstituted-[1,2,4]triazolo[1,5-a][1,3,5]triazine derivatives as adenosine receptor antagonists: A preliminary inspection of ligand-receptor recognition process. Bioorg Med Chem 2010;18:2524-36.

[22] Pastorin G, Da Ros T, Spalluto G, Deflorian F, Moro S, Cacciari B, et al. Pyrazolo[4,3-e]-1,2,4-triazolo[1,5-c]pyrimidine derivatives as adenosine receptor antagonists. Influence of the N5 substituent on the affinity at the human A 3 and A 2B adenosine receptor subtypes: a molecular modeling investigation. Journal of Medicinal Chemistry 2003;46:4287-96.

[23] Beukers MW, den Dulk H, van Tilburg EW, Brouwer J, ljzerman AP. Why are $\mathrm{A}(2 \mathrm{~B})$ receptors low-affinity adenosine receptors? Mutation of Asn273 to Tyr increases affinity of human $\mathrm{A}(2 \mathrm{~B})$ receptor for 2-(1-Hexynyl)adenosine. Mol Pharmacol 2000;58:1349-56.

[24] Matharu AL, Mundell SJ, Benovic JL, Kelly E. Rapid agonist-induced desensitization and internalization of the $A(2 B)$ adenosine receptor is mediated by a serine residue close to the $\mathrm{COOH}$ terminus. J Biol Chem 2001;276:30199207.

[25] Peeters MC, van Westen GJ, Guo D, Wisse LE, Müller CE, Beukers MW, et al. GPCR structure and activation: an essential role for the first extracellular loop in activating the adenosine $A_{2 B}$ receptor. FASEB J 2010;4:4.

[26] Ivanov AA, Palyulin VA, Zefirov NS. Computer aided comparative analysis of the binding modes of the adenosine receptor agonists for all known subtypes of adenosine receptors. J Mol Graph Model 2007;25:740-54.

[27] Ivanov AA, Baskin, II, Palyulin VA, Piccagli L, Baraldi PG, Zefirov NS. Molecular modeling and molecular dynamics simulation of the human $A_{2 B}$ adenosine receptor. The study of the possible binding modes of the $A_{2 B}$ receptor antagonists. J Med Chem 2005;48:6813-20.

[28] Kim YC, de Zwart M, Chang L, Moro S, von Frijtag Drabbe Kunzel JK, Melman N, et al. Derivatives of the triazoloquinazoline adenosine antagonist (CGS 15943) having high potency at the human $A_{2 B}$ and $A_{3}$ receptor subtypes. Journal of Medicinal Chemistry 1998;41:2835-45.

[29] Sherbiny FF, Schiedel AC, Maass A, Müller CE. Homology modelling of the human adenosine $\mathrm{A} 2 \mathrm{~B}$ receptor based on $\mathrm{X}$-ray structures of bovine rhodopsin, the beta2-adrenergic receptor and the human adenosine $A_{2 A}$ receptor. $\mathrm{J}$ Comput Aided Mol Des 2009;23:807-28.

[30] Ballesteros J, Weinstein, H. Integrated methods for the constructionof threedimensional models of structure-function relations in $\mathrm{G}$ protein-coupled receptors. Meth Neurosci 1995;25:366-428. 
[31] de Graaf C, Foata N, Engkvist O, Rognan D. Molecular modeling of the second extracellular loop of G-protein coupled receptors and its implication on structurebased virtual screening. Proteins 2008;71:599-620.

[32] Avlani VA, Gregory KJ, Morton CJ, Parker MW, Sexton PM, Christopoulos A. Critical Role for the Second Extracellular Loop in the Binding of Both Orthosteric and Allosteric G Protein-coupled Receptor Ligands. J Biol Chem 2007;282:25677-86.

[33] http://www.ebi.ac.uk/Tools/clustalw2/. (27.01.2011).

[34] http://www.ebi.ac.uk/Tools/emboss/align/. (27.01.2011).

[35] http://www.cbs.dtu.dk/services/NetNGlyc/. (27.01.2011).

[36] http://www.sacs.ucsf.edu/TOPO2/. (27.01.2011).

[37] http://modbase.compbio.ucsf.edu/modloop/. (27.01.2011).

[38] http://ambermd.org/. (27.01.2011).

[39] http://www.ebi.ac.uk/thornton-srv/software/PROCHECKJ. (27.01.2011).

[40] Sippl MJ. Recognition of errors in three-dimensional structures of proteins. Proteins 1993;17:355-62.

[41] Lowry $\mathrm{OH}$, Rosebrough NJ, Farr AL, Randall RJ. Protein measurement with the Folin phenol reagent. J Biol Chem 1951;193:265-75.

[42] Hillmann P, Ko GY, Spinrath A, Raulf A, von Kugelgen I, Wolff SC, et al. Key determinants of nucleotide-activated G protein-coupled P2Y(2) receptor function revealed by chemical and pharmacological experiments, mutagenesis and homology modeling. J Med Chem 2009;52:2762-75.

[43] Motulsky HJ, Christopoulos A. Fitting models to biological data using linear and nonlinear regression. San Diego: GraphPad Software Inc., 2003.

[44] Nordstedt C, Fredholm BB. A modification of a protein-binding method for rapid quantification of cAMP in cell-culture supernatants and body fluid. Analytical Biochemistry 1990;189:231-4.

[45] Jaakola VP, Griffith MT, Hanson MA, Cherezov V, Chien EY, Lane JR, et al. The 2.6 angstrom crystal structure of a human $\mathrm{A}_{2 \mathrm{~A}}$ adenosine receptor bound to an antagonist. Science 2008;322:1211-7.

[46] Peeters MC, van Westen GJ, Li Q, ljzerman AP. Importance of the extracellular loops in $\mathrm{G}$ protein-coupled receptors for ligand recognition and receptor activation. Trends Pharmacol Sci 2011;32:35-42.

[47] Karnik SS, Sakmar TP, Chen HB, Khorana HG. Cysteine residues 110 and 187 are essential for the formation of correct structure in bovine rhodopsin.

Proceedings of the National Academy of Sciences of the United States of America 1988;85:8459-63.

[48] Ding Z, Kim S, Dorsam RT, Jin J, Kunapuli SP. Inactivation of the human P2Y 12 receptor by thiol reagents requires interaction with both extracellular cysteine residues, Cys17 and Cys270. Blood 2003;101:3908-14.

[49] Shi L, Javitch JA. The second extracellular loop of the dopamine D2 receptor lines the binding-site crevice. Proc Natl Acad Sci U S A 2004;101:440-5.

[50] Duong HT, Gao ZG, Jacobson KA. Nucleoside modification and concerted mutagenesis of the human $A_{3}$ adenosine receptor to probe interactions between the 2-position of adenosine analogs and GIn167 in the second extracellular loop. Nucleosides Nucleotides Nucleic Acids 2005;24:1507-17. 
[51] Bokoch MP, Zou Y, Rasmussen SG, Liu CW, Nygaard R, Rosenbaum DM, et al. Ligand-specific regulation of the extracellular surface of a G-protein-coupled receptor. Nature 2010;463:108-12.

[52] Ai LS, Liao F. Mutating the four extracellular cysteines in the chemokine receptor CCR6 reveals their differing roles in receptor trafficking, ligand binding, and signaling. Biochemistry 2002;41:8332-41.

[53] McGinnes LW, Morrison TG. Disulfide bond formation is a determinant of glycosylation site usage in the hemagglutinin-neuraminidase glycoprotein of Newcastle disease virus. J Virol 1997;71:3083-9.

[54] Azimi I, Wong JW, Hogg PJ. Control of mature protein function by allosteric disulfide bonds. Antioxid Redox Signal 2011;14:113-26.

[55] Rubenstein LA, Zauhar RJ, Lanzara RG. Molecular dynamics of a biophysical model for beta2-adrenergic and $\mathrm{G}$ protein-coupled receptor activation. J Mol Graph Model 2006;25:396-409.

[56] Mercier RW, Pei Y, Pandarinathan L, Janero DR, Zhang J, Makriyannis A. hCB2 ligand-interaction landscape: cysteine residues critical to biarylpyrazole antagonist binding motif and receptor modulation. Chem Biol 2010;17:1132-42.

[57] Varani K, Caramori G, Vincenzi F, Tosi A, Barczyk A, Contoli M, et al. Oxidative/nitrosative stress selectively altered $A 2 B$ adenosine receptors in chronic obstructive pulmonary disease. FASEB J 2009;14:14.

[58] Goddard WA, 3rd, Kim SK, Li Y, Trzaskowski B, Griffith AR, Abrol R. Predicted 3D structures for adenosine receptors bound to ligands: comparison to the crystal structure. J Struct Biol 2010;170:10-20.

[59] Barrondo S, Salles J. Allosteric modulation of 5-HT(1A) receptors by zinc: Binding studies. Neuropharmacology 2009;56:455-62. Epub 2008 Oct 14.

[60] Schetz JA, Chu A, Sibley DR. Zinc modulates antagonist interactions with D2-like dopamine receptors through distinct molecular mechanisms. J Pharmacol Exp Ther 1999;289:956-64.

[61] Elling CE, Frimurer TM, Gerlach LO, Jorgensen R, Holst B, Schwartz TW. Metal ion site engineering indicates a global toggle switch model for seventransmembrane receptor activation. J Biol Chem 2006;281:17337-46. Epub 2006 Mar 27.

[62] Klco JM, Lassere TB, Baranski TJ. C5a receptor oligomerization. I. Disulfide trapping reveals oligomers and potential contact surfaces in a G protein-coupled receptor. J Biol Chem 2003;278:35345-53.

[63] Berthouze M, Rivail L, Lucas A, Ayoub MA, Russo O, Sicsic S, et al. Two transmembrane Cys residues are involved in 5-HT4 receptor dimerization. Biochem Biophys Res Commun 2007;356:642-7. 
Table 1. Evaluation of the goodness of different $A_{2 A}$ and $A_{2 B}$ receptor models after simulation

7

8

9disulfide bonds fixed

m1 $A_{2 A}$

m2 $\mathbf{A}_{2 A}$

m1 $A_{2 B}$

m2 $A_{2 B}$

m3 $A_{2 B}$

C72-C167

C72-C166

C78-C171

C78-C171

m4 A

C74-C146

C78-C171

C77-C166

C259-C262

11

0.4

$-4.3$

$-4.11$

0.7

0.7

0.7

C72-C167

C78-C171

13PROCHECK psi/phi

1.1

4.11

$-4.06$

$-3.91$

$-4.17$

1.0

${ }_{16}^{15}$ PROSAII

$17^{Z}$-score ${ }^{\text {b }}$

1.0

0.8

1.3

1.9

1.7

$-4.42$

${ }_{18} \mathrm{RMSD}^{\mathrm{C}}$ relative to

$1.0-1.8$

(1.3.

0.9

0.8

0.7

1.0

0.8

0.8

22initial structure $[\AA]$

${ }^{a}$ psi (angle between carbon and carbonyl) and phi angels (angle between carbon and nitrogen) are determined using a Ramachandran plot, which is a way to visualize the dihedral angles (psi against phi) of amino acid residues in protein structures. Lower values indicate better quality.

${ }^{b}$ The Z-score indicates the overall model quality, its value is displayed in a plot which shows the local model quality by plotting energies as a function of the amino acid sequence position. In general, positive values correspond to problematic parts of the input structure, negative values indicate good quality.

${ }^{\mathrm{C}} \mathrm{RMSD}$ : root mean square distance. Lower overall values indicate good accordance between two models. 
Table 2: Affinities of the antagonist PSB-603 and the agonist NECA at the human $A_{2 B}$ receptor mutants and the wt receptor determined in radioligand binding studies versus $\left[{ }^{3} \mathrm{H}\right] \mathrm{PSB}-603(0.3 \mathrm{nM})$. Data are means \pm SEM of three independent experiments unless otherwise noted.

\begin{tabular}{|c|c|c|}
\hline wt or mutant & $\begin{array}{c}\text { PSB-603 } \\
I_{50} \pm \text { SEM (nM) }\end{array}$ & $\begin{array}{c}\text { NECA } \\
I \mathrm{IC}_{50} \pm \mathrm{SEM}(\mathrm{nM})\end{array}$ \\
\hline wt & $2.39 \pm 0.71^{\mathrm{a}}$ & $5300 \pm 946^{b}$ \\
\hline C78S & $-^{c}$ & $-^{c}$ \\
\hline C154S & $19.0 \pm 4.3^{* \star *}$ & $4970 \pm 490^{n s}$ \\
\hline C166S & $1.41 \pm 0.15^{\mathrm{ns}}$ & $4253 \pm 766^{\mathrm{ns}}$ \\
\hline C167S & $1.60 \pm 0.38^{n s}$ & $2933 \pm 121^{\mathrm{ns}}$ \\
\hline C166S-C167S & $5.49 \pm 1.30^{d n s}$ & $3920 \pm 517^{\mathrm{ns}}$ \\
\hline C171S & $-{ }^{\mathrm{C}}$ & $-{ }^{\mathrm{C}}$ \\
\hline
\end{tabular}


Table 3: $\mathrm{EC}_{50}$ values determined for the agonists NECA and BAY60-6583 in cAMP accumulation assays at the wt and the mutants of the human $A_{2 B}$ receptor. Data are means \pm SEM of three independent experiments unless otherwise noted.

\begin{tabular}{lcccc}
\hline & NECA & \multicolumn{3}{c}{ BAY60-6583 } \\
wt or mutant & EC $_{50 \pm \text { SEM }(n M)}$ & fold shift $^{\mathrm{a}}$ & EC $_{50} \pm$ SEM $(\mathrm{nM})$ & fold shift $^{\mathrm{a}}$ \\
\hline wt & $58.1 \pm 11.7^{\mathrm{b}}$ & & $62.8 \pm 7.3^{\mathrm{C}}$ & \\
C78S & $397000 \pm 7700^{* * *}$ & 6830 & $>100000^{* * *}$ & $>1590$ \\
C154S & $159 \pm 29^{* *}$ & 2.7 & $35.9^{*}$ & 0.6 \\
C166S & $71.1 \pm 12.6^{\mathrm{ns}}$ & 1.2 & $26.8 \pm 6.1^{*}$ & 0.4 \\
C167S & $64.5 \pm 6.5^{\mathrm{ns}}$ & 1.1 & $26.3 \pm 5.5^{*}$ & 0.4 \\
C166S-C167S & $94.1 \pm 13.0^{\mathrm{ns}}$ & 1.6 & $40.6^{\mathrm{ns}}$ & 0.6 \\
C171S & $256000 \pm 28^{* * *}$ & 4400 & $>100000^{* * *}$ & $>1590$ \\
\hline
\end{tabular}

${ }^{\mathrm{a}}$ The shift represents the ratio $\mathrm{EC}_{50}$ (mutant) : $\mathrm{EC}_{50}(\mathrm{wt}) ;{ }^{\mathrm{b}} \mathrm{n}=6 ;{ }^{\mathrm{c}} \mathrm{n}=5$; Results of a two-tailed t-test:

${ }^{n s}$ not significantly different from wildtype, ${ }^{*} p<0.05,{ }^{* *} p<0.01$, ${ }^{\star \star *} p<0.001$ 
Figure 1: Topology model of the human $A_{2 B}$ receptor. The topology of the human $A_{2 B}$ receptor is shown as a snakeplot diagram drawn with TOPO2 [36]. The amino acids are shown in the one-letter code. Cysteine residues which were exchanged for serine by site-directed mutagenesis are shown as squares and color-coded as follows: C78, red; C154, purple, C166, cyan; C167, blue; C171, green. The two potential glycosylation sites are shown as up-arrows: brown: N153; orange: N163. C72 (magenta) is shown as hexagon.

Figure 2: (A) Alignments of the first and second extracellular loops of the human $A_{2 A}$ and $A_{2 B}$ receptors. The alignment was done using Clustal W2 [33]. The following amino acid residues are highlighted: magenta: $\mathrm{C} 71^{\mathrm{A} 2 \mathrm{~A}} / \mathrm{C} 72^{\mathrm{A} 2 \mathrm{~B}}$; red: conserved cysteine $\mathrm{C} 3.25$ in TMD3, C77 ${ }^{\mathrm{A} 2 \mathrm{~A}} / \mathrm{C} 78^{\mathrm{A} 2 \mathrm{~B}}$; purple: $\mathrm{C} 146^{\mathrm{A} 2 \mathrm{~A}} / \mathrm{C} 154^{\mathrm{A} 2 \mathrm{~B}}$; cyan: $\mathrm{C} 166^{\mathrm{A} 2 \mathrm{~B}}$; blue: $\mathrm{C} 159^{\mathrm{A} 2 \mathrm{~A}} / \mathrm{C} 167^{\mathrm{A} 2 \mathrm{~B}}$; green: $\mathrm{C} 166^{\mathrm{A} 2 \mathrm{~A}} / \mathrm{C} 171^{\mathrm{A} 2 \mathrm{~B}}$; potential $\mathrm{N}$ glycosylation sites: brown: $\mathrm{N} 153^{\mathrm{A} 2 \mathrm{~B}}$; orange: $\mathrm{N} 161^{\mathrm{A} 2 \mathrm{~A}} / \mathrm{N} 163^{\mathrm{A} 2 \mathrm{~B}}$; underlined: $\mathrm{N}$ glycosylation seqouns; bold and italic: $\beta$-sheets; ECL: extracellular loop; * identical amino acid residue, : conserved amino acid substitution; . semi-conserved amino acid substitution. Amino acid positions of cysteine residues are given for the human $A_{2 A}$ and the $A_{2 B}$ receptor. $(B)$ Cysteine residues involved in disulfide bonds found in the crystal structure of the human $A_{2 A}$ receptor [45] and cysteine residues involved in predicted disulfide bonds in the human $A_{2 B}$ receptor.

Figure 3: Molecular models of the human adenosine $A_{2 B}$ receptor. (A) Initial model without fixed disulfide bonds (starting conformation). (B) Model $1 \mathrm{~A}_{2 \mathrm{~B}}$ after simulation with one fixed disulfide bond: $\mathrm{C} 78-\mathrm{C} 171\left(\mathrm{~m}_{1} \mathrm{~A}_{2 \mathrm{~B}}\right)$. The following amino acids are shown 
as stick models: magenta: C72; red: C78; purple: C154; cyan: C166; blue: C167; green: C171; potential N glycosylation sites: brown: N153 and orange: N163.

Figure 4: Comparison of B-factors for the disulfide bond predictions of the four simulated models of the human $A_{2 B}$ receptor and for model 2 of the human $A_{2 A}$ receptor. B-factors indicate the true static or dynamic mobility of an atom, it can also indicate where there are errors in model building. Higher values indicate higher mobility of residues.

Figure 5: Effect of preincubation with DTT on $A_{2 B}$ receptor activity. NECA-induced cAMP accumulation in $\mathrm{CHO}$ cells stably expressing the human $\mathrm{A}_{2 \mathrm{~B}}$ receptor without and with DTT pretreatment (10 $\mathrm{mM} \mathrm{DTT}, 2 \mathrm{~h}$ at $37^{\circ} \mathrm{C}$ ). Data points represent mean values \pm SEM from three independent experiments performed in triplicates. Determined $\mathrm{EC}_{50}$ values: control: $36.6 \pm 4.8 \mathrm{nM}$, DTT-pretreated: $2720 \pm 570 \mathrm{nM}$.

Figure 6: Competition binding experiments of standard ligands at HA-tagged and untagged human adenosine $A_{2 B}$ receptors. Radioligand binding experiments were performed at membrane preparations of $\mathrm{CHO}$ cells stably expressing the human $A_{2 B}$ receptor using the antagonist $\left[{ }^{3} \mathrm{H}\right] \mathrm{PSB}-603(0.3 \mathrm{nM})$ as a radioligand. Data points represent means \pm SEM of three independent experiments performed in triplicates. $I C_{50}$ and $\mathrm{K}_{\mathrm{i}}$ values are listed in supplemental table 1. Results from untagged and HA-tagged receptors were not significantly different. 
Figure 7: Saturation binding of $\left[{ }^{3} \mathrm{H}\right] \mathrm{PSB}-603$ to human adenosine $\mathrm{A}_{2 \mathrm{~B}}$ receptors $(\mathbf{A})$ without and (B) with HA tag, stably expressed in $\mathrm{CHO}$ cells. Data points represent means \pm SEM of three independent experiments performed in duplicates. $K_{D}$ value for untagged $A_{2 B}$ receptors: $0.403 \pm 0.188 \mathrm{nM}$, for HA-tagged $A_{2 B}$ receptors: $0.473 \pm 0.170$ $\mathrm{nM}$ (not significantly different). Determined $B_{\max }$ values were $502 \pm 57 \mathrm{fmol} / \mathrm{mg}$ protein (A), and $283 \pm 37 \mathrm{fmol} / \mathrm{mg}$ protein $(\mathbf{B})$.

Figure 8: Agonist induced cAMP accumulation in $\mathrm{CHO}$ cells stably expressing HAtagged or untagged $A_{2 B}$ receptors using (A) NECA, or (B) BAY60-6583 as agonists. Data points represent mean values \pm SEM from three independent experiments performed in duplicates. Corresponding $\mathrm{EC}_{50}$ values are summarized in supplemental table 1. Results from untagged and HA-tagged receptors were not significantly different.

Figure 9: Cell surface expression levels of mutant receptors in comparison to the wt $A_{2 B}$ receptor determined by ELISA. Values were normalized versus values from cells transfected with the empty plasmid, set at $0 \%$ and values from cells expressing the wt receptor, set at $100 \%$. Data represent the mean values \pm SEM of two (C166S-C167S, C171S), three (empty, C78S, C154S, C166S, C167S), or six (wt) independent experiments performed in triplicates.

Figure 10: Agonist-induced cAMP accumulation studies in $\mathrm{CHO}$ cells stably expressing the wt and cysteine mutants of the human $A_{2 B}$ receptor using $(\mathbf{A})$ NECA, and (B) BAY60-6583 as agonists. Data represent mean curves \pm SEM from six (wt) or three 
1

2 (mutants) independent experiments performed in duplicates. Corresponding $\mathrm{EC}_{50}$ values are summarized in table 3 . The C78S and C171S mutants could not be activated by BAY60-6583 at concentrations which were soluble (solubility $<30 \mu \mathrm{M}$ ). 
Table 1. Evaluation of the goodness of different $A_{2 A}$ and $A_{2 B}$ receptor models after simulation

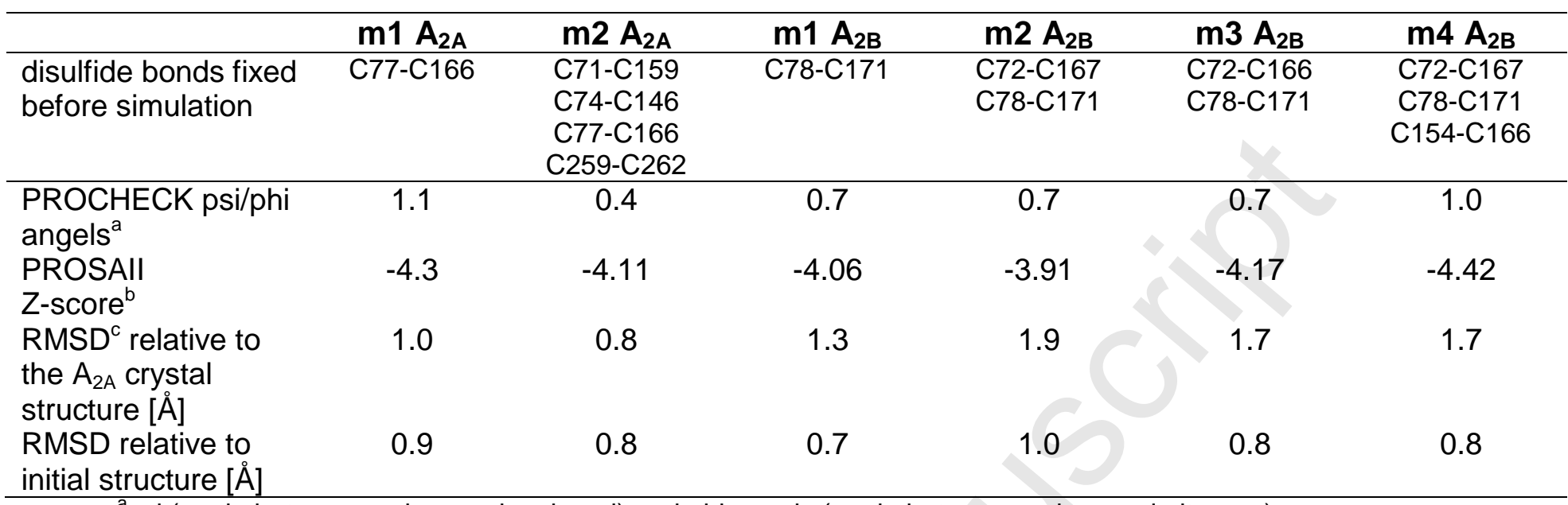

${ }^{a}$ psi (angle between carbon and carbonyl) and phi angels (angle between carbon and nitrogen) are determined using a Ramachandran plot, which is a way to visualize the dihedral angles (psi against phi) of amino acid residues in protein structures. Lower values indicate better quality.

${ }^{b}$ The Z-score indicates the overall model quality, its value is displayed in a plot which shows the local model quality by plotting energies as a function of the amino acid sequence position. In general, positive values correspond to problematic parts of the input structure, negative values indicate good quality.

${ }^{\mathrm{c}} \mathrm{RMSD}$ : root mean square distance. Lower overall values indicate good accordance between two models. 
Table 2: Affinities of the antagonist PSB-603 and the agonist NECA at the human $A_{2 B}$ receptor mutants and the wt receptor determined in radioligand binding studies versus $\left[{ }^{3} \mathrm{H}\right] \mathrm{PSB}-603(0.3 \mathrm{nM})$. Data are means \pm SEM of three independent experiments unless otherwise noted.

\begin{tabular}{|c|c|c|}
\hline wt or mutant & $\begin{array}{c}\text { PSB-603 } \\
I_{50} \pm \text { SEM (nM) }\end{array}$ & $\begin{array}{c}\text { NECA } \\
1 \mathrm{C}_{50} \pm \mathrm{SEM}(\mathrm{nM})\end{array}$ \\
\hline wt & $2.39 \pm 0.71^{a}$ & $5300 \pm 946^{b}$ \\
\hline C78S & $-c$ & $-c$ \\
\hline C154S & $19.0 \pm 4.3^{* \star *}$ & $4970 \pm 490^{\mathrm{ns}}$ \\
\hline C166S & $1.41 \pm 0.15^{\mathrm{ns}}$ & $4253 \pm 766^{\mathrm{ns}}$ \\
\hline C167S & $1.60 \pm 0.38^{\mathrm{ns}}$ & $2933 \pm 121^{\mathrm{ns}}$ \\
\hline $\begin{array}{l}\text { C166S-C167S } \\
\text { C171S }\end{array}$ & $\begin{array}{c}5.49 \pm 1.30^{d \mathrm{~ns}} \\
-c\end{array}$ & $\begin{array}{c}3920 \pm 517^{\mathrm{ns}} \\
-c\end{array}$ \\
\hline
\end{tabular}


Table 3: $\mathrm{EC}_{50}$ values determined for the agonists NECA and BAY60-6583 in cAMP accumulation assays at the wt and the mutants of the human $A_{2 B}$ receptor. Data are means \pm SEM of three independent experiments unless otherwise noted.

\begin{tabular}{|c|c|c|c|c|}
\hline wt or mutant & $\begin{array}{c}\text { NECA } \\
\mathrm{EC}_{50} \pm \mathrm{SEM}(\mathrm{nM})\end{array}$ & fold shift ${ }^{\mathrm{a}}$ & $\begin{array}{c}\text { BAY60-6583 } \\
\mathrm{EC}_{50} \pm \mathrm{SEM}(\mathrm{nM})\end{array}$ & fold shift ${ }^{\mathrm{a}}$ \\
\hline wt & $58.1 \pm 11.7^{b}$ & & $62.8 \pm 7.3^{\mathrm{c}}$ & \\
\hline C78S & $397000 \pm 7700^{* * *}$ & 6830 & $>100000^{* * *}$ & $>1590$ \\
\hline C154S & $159 \pm 29 * *$ & 2.7 & $35.9 *$ & 0.6 \\
\hline C166S & $71.1 \pm 12.6^{\mathrm{ns}}$ & 1.2 & $26.8 \pm 6.1$ * & 0.4 \\
\hline C167S & $64.5 \pm 6.5^{\mathrm{ns}}$ & 1.1 & $26.3 \pm 5.5$ * & 0.4 \\
\hline C166S-C167S & $94.1 \pm 13.0^{\mathrm{ns}}$ & 1.6 & $40.6^{\text {ns }}$ & 0.6 \\
\hline C171S & $256000 \pm 28900^{* * *}$ & 4400 & $>100000^{* * *}$ & $>1590$ \\
\hline
\end{tabular}



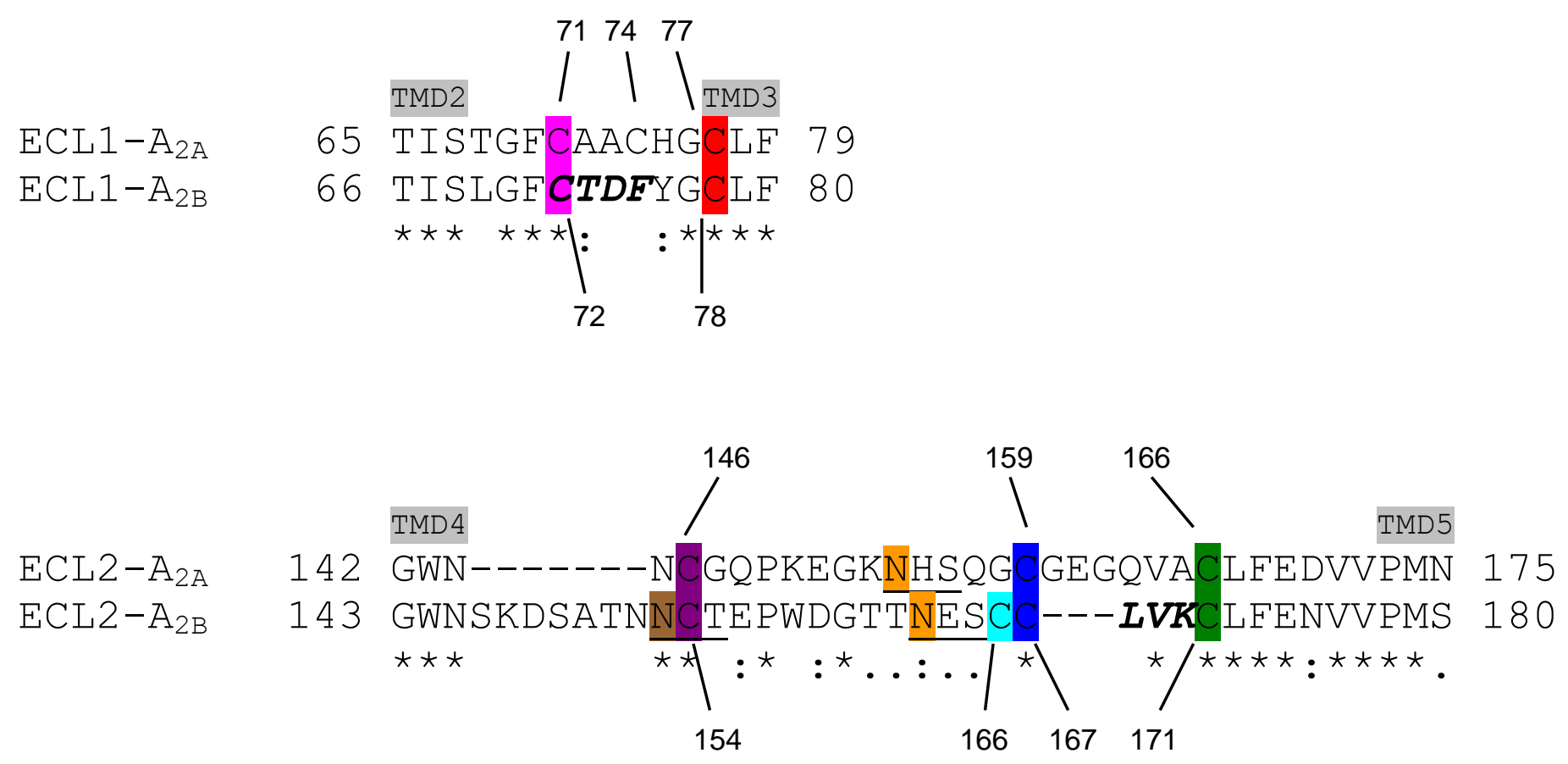

\section{B}

$\begin{array}{cc}\mathbf{A}_{2 \mathbf{A}} & \mathbf{A}_{2 \mathbf{B}} \\ \mathrm{C} 71-\mathrm{C} 159 & \mathrm{C} 72-\mathrm{C} 167 ? \\ \mathrm{C} 74-\mathrm{C} 146 & \mathrm{C} 78-\mathrm{C} 171 \\ \text { C77-C166 } & \end{array}$




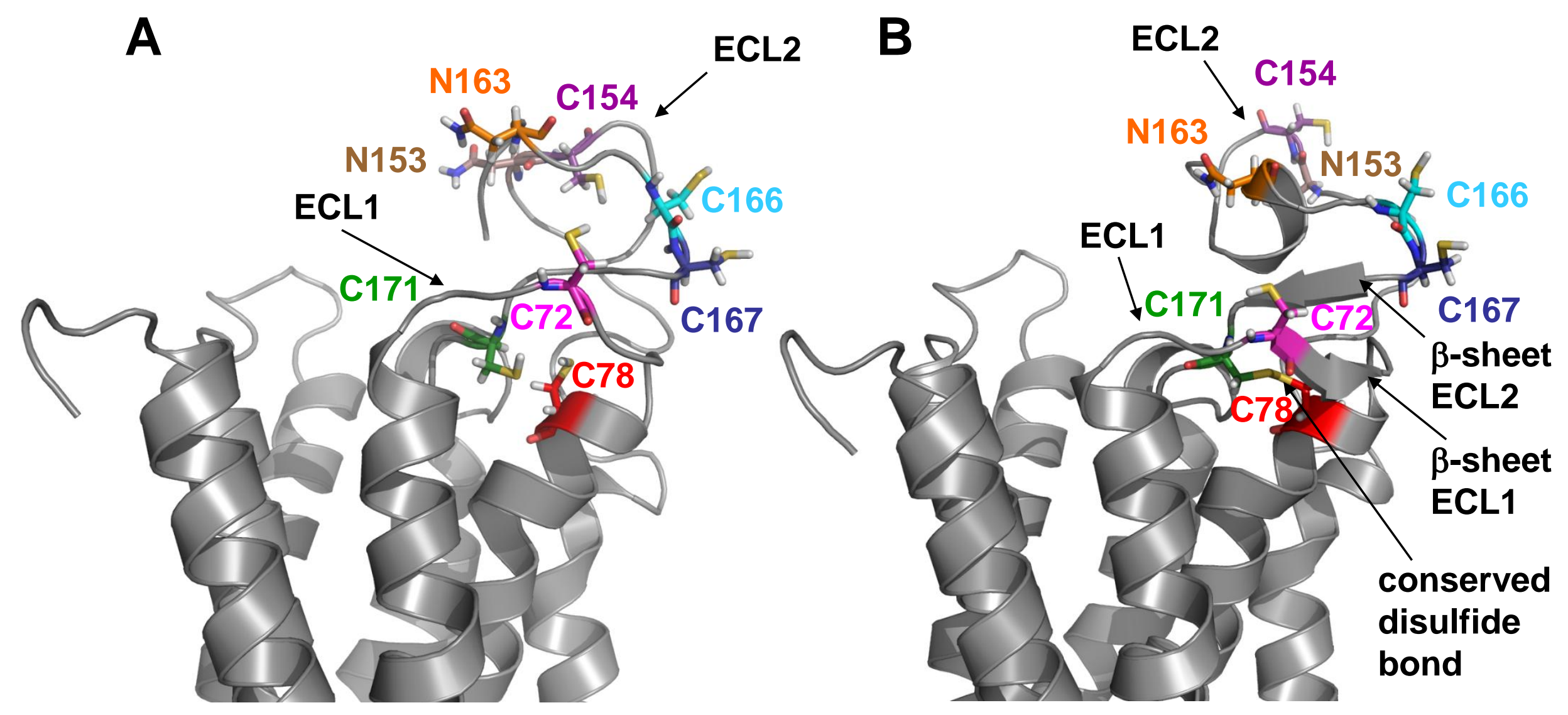




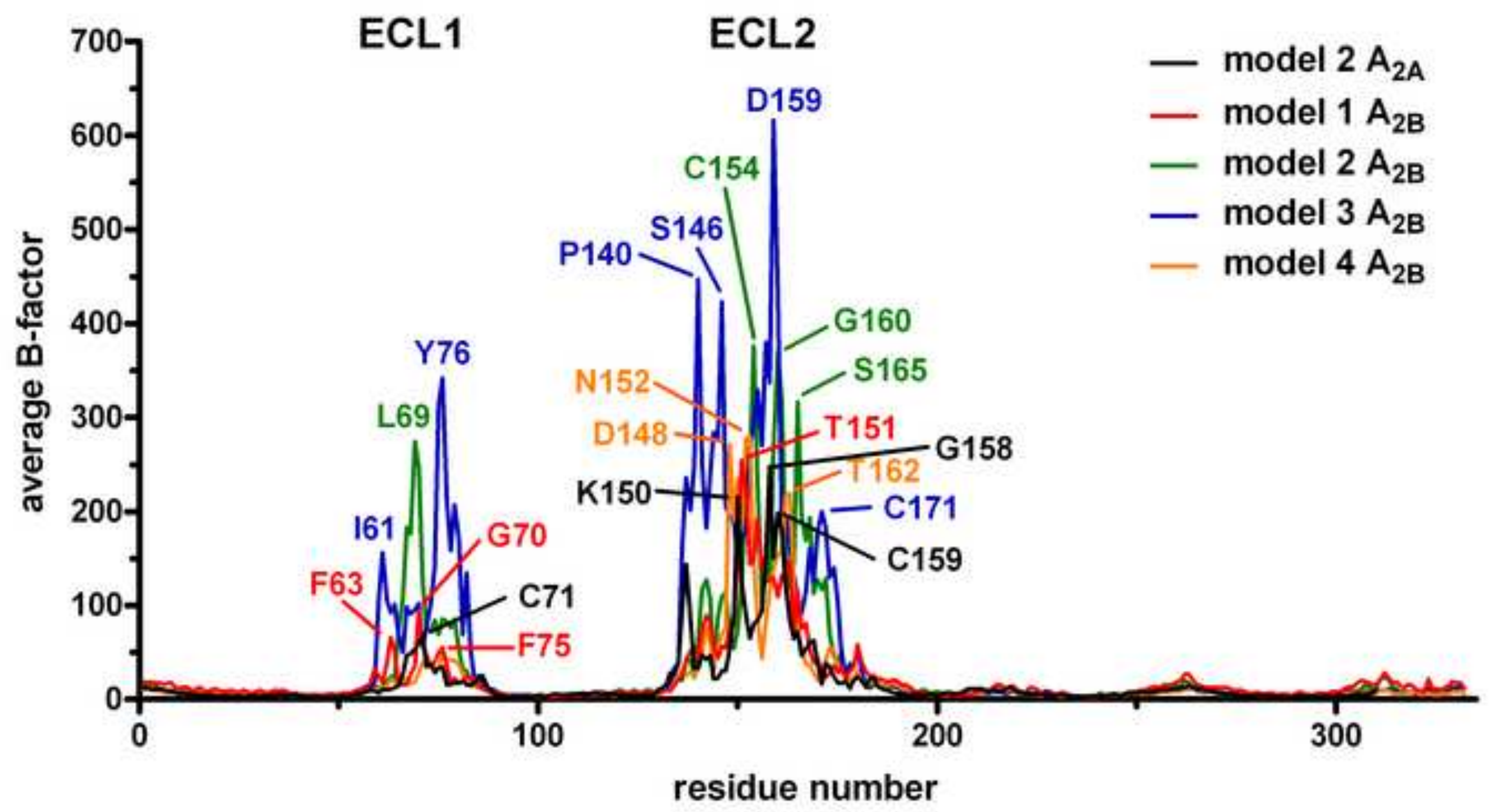




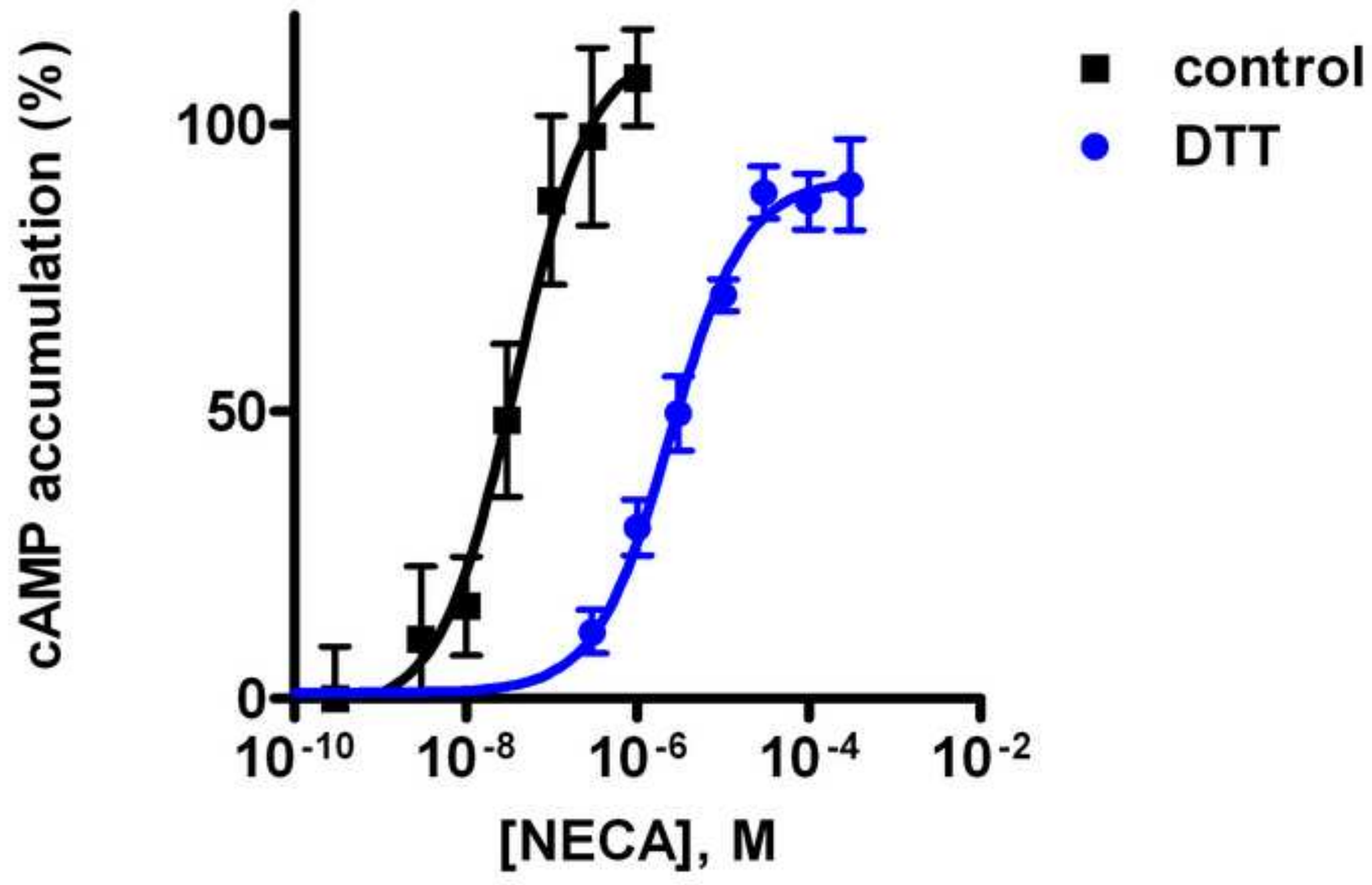




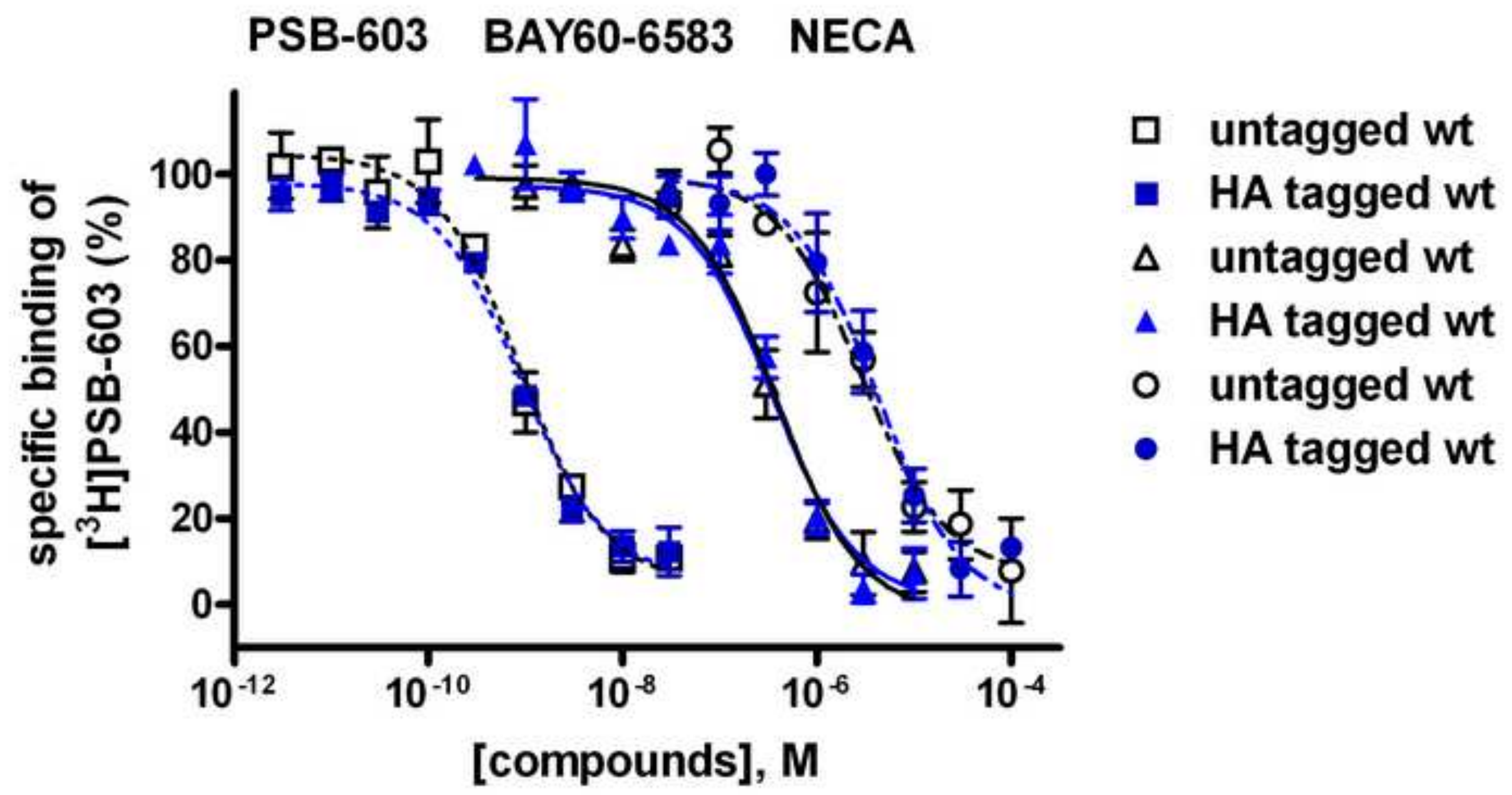




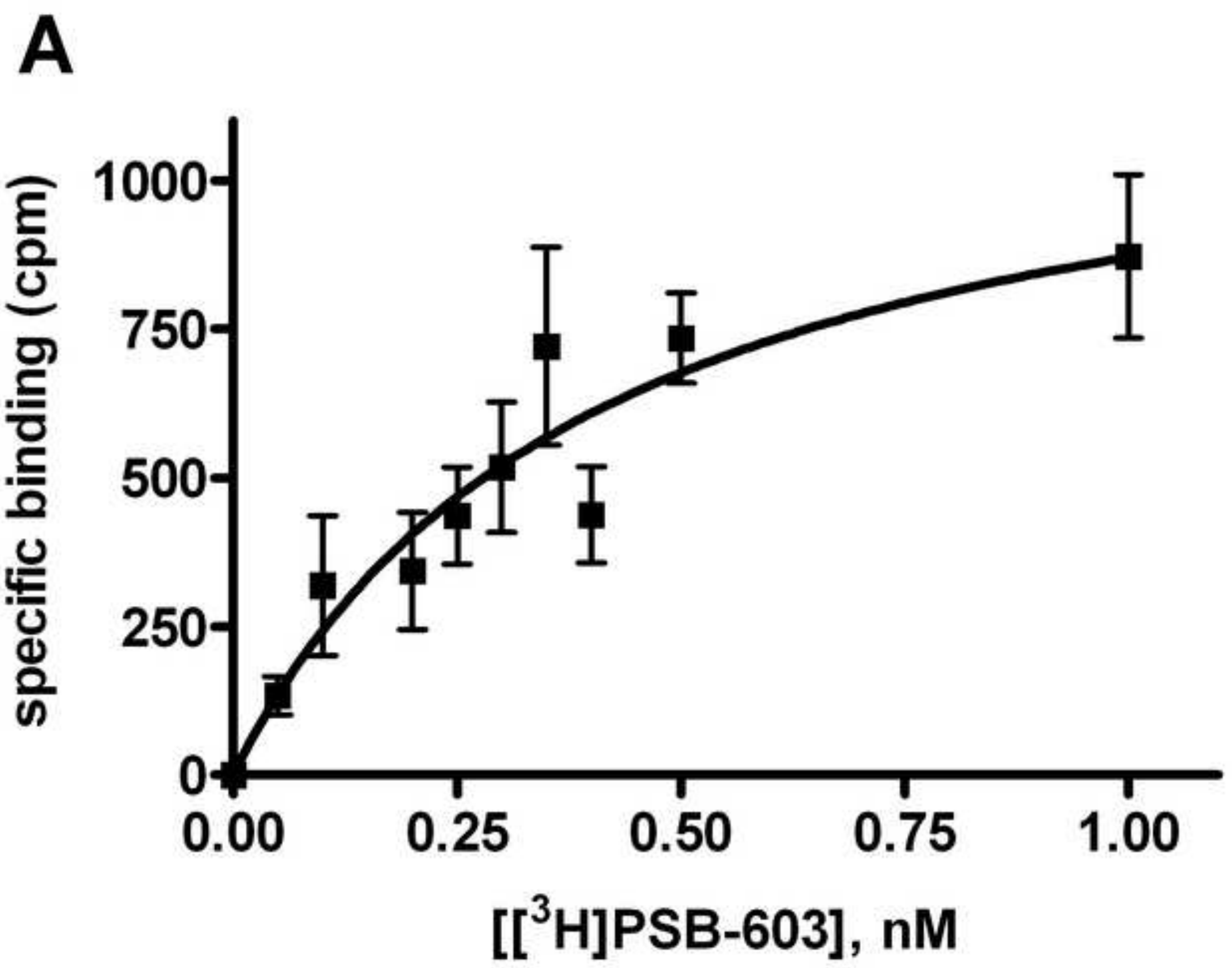




\section{B}

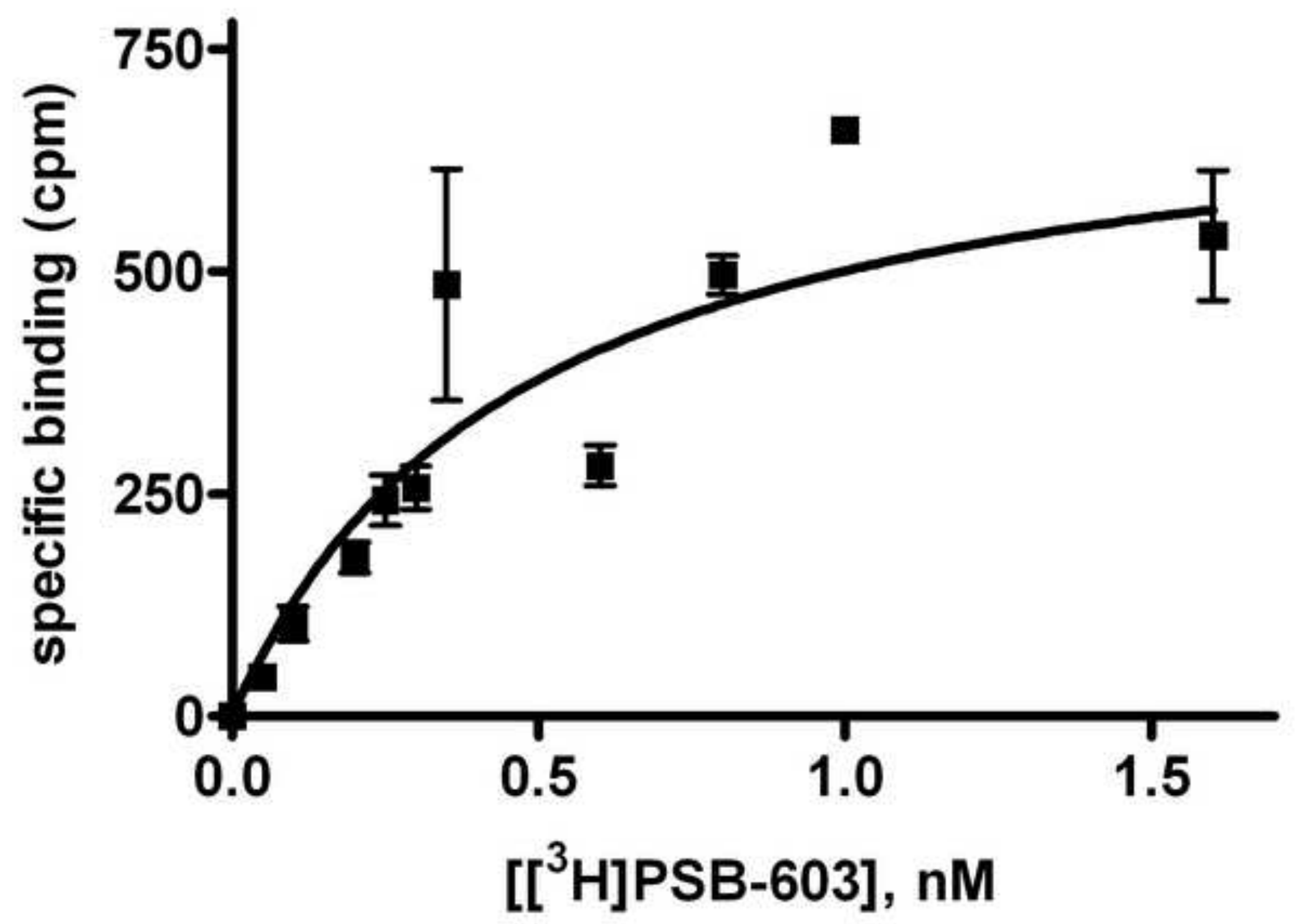


A

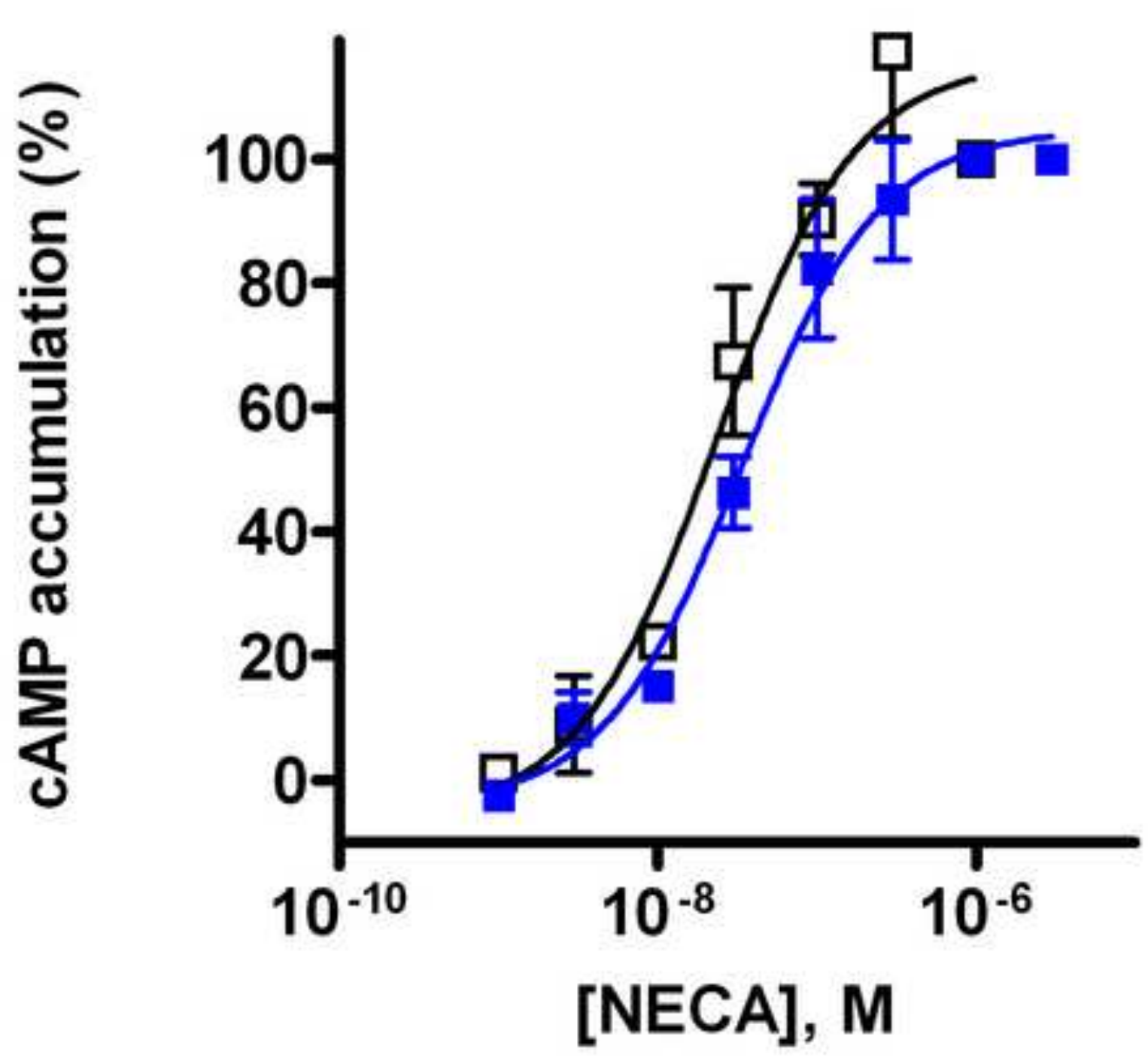

ㄴ untagged wt - HA tagged wt 
B

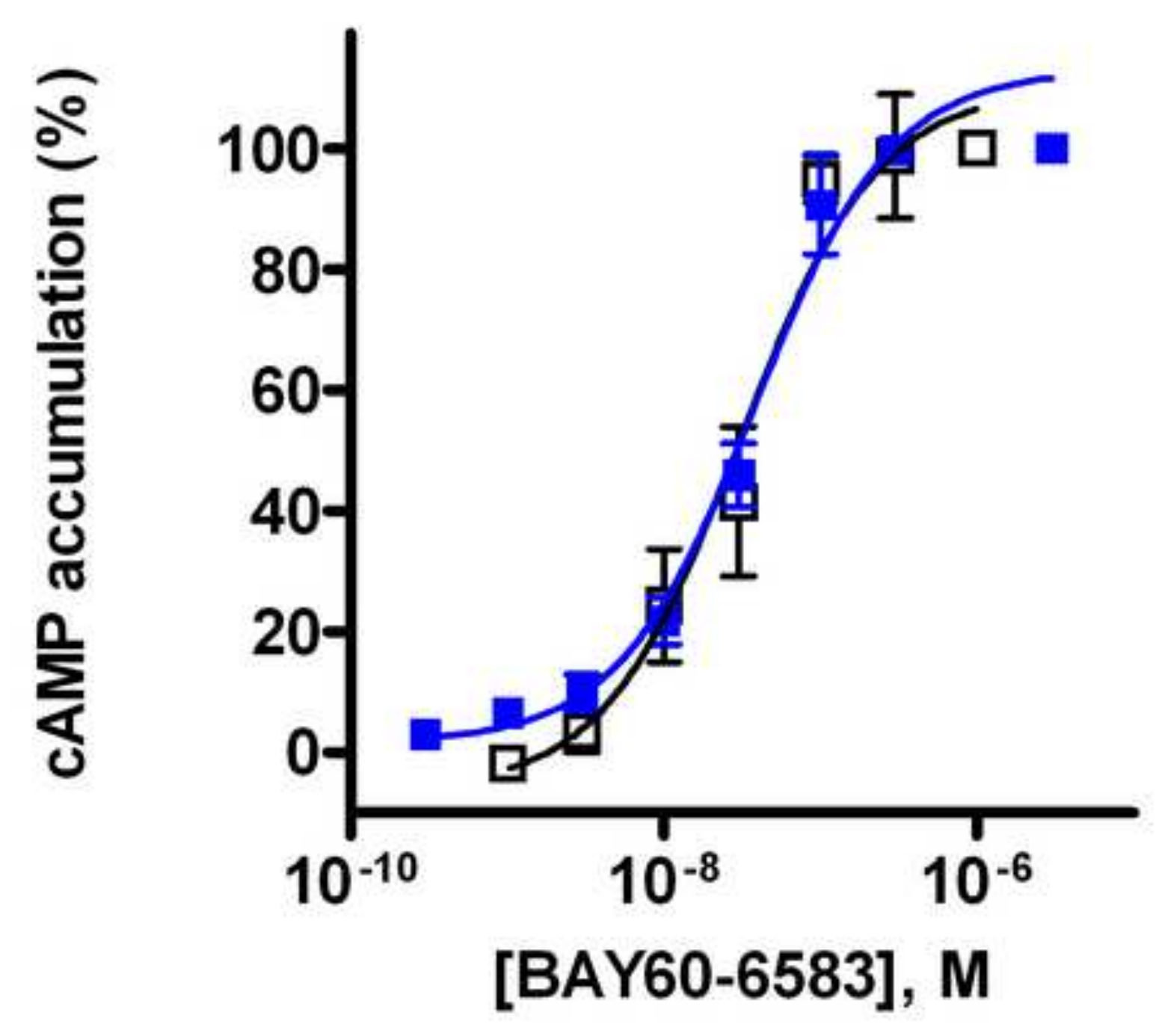

ㄴ untagged wt - HA tagged wt 


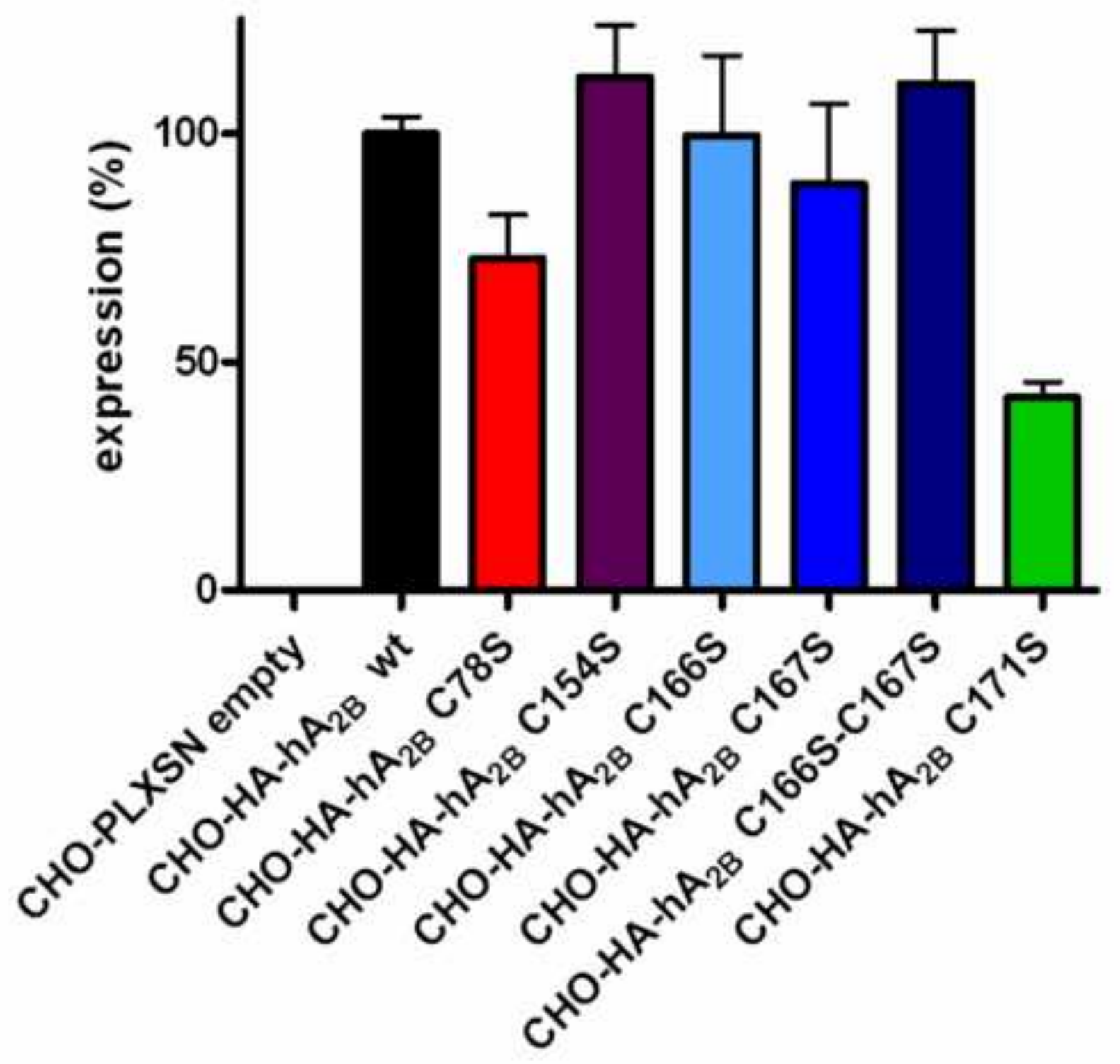


A
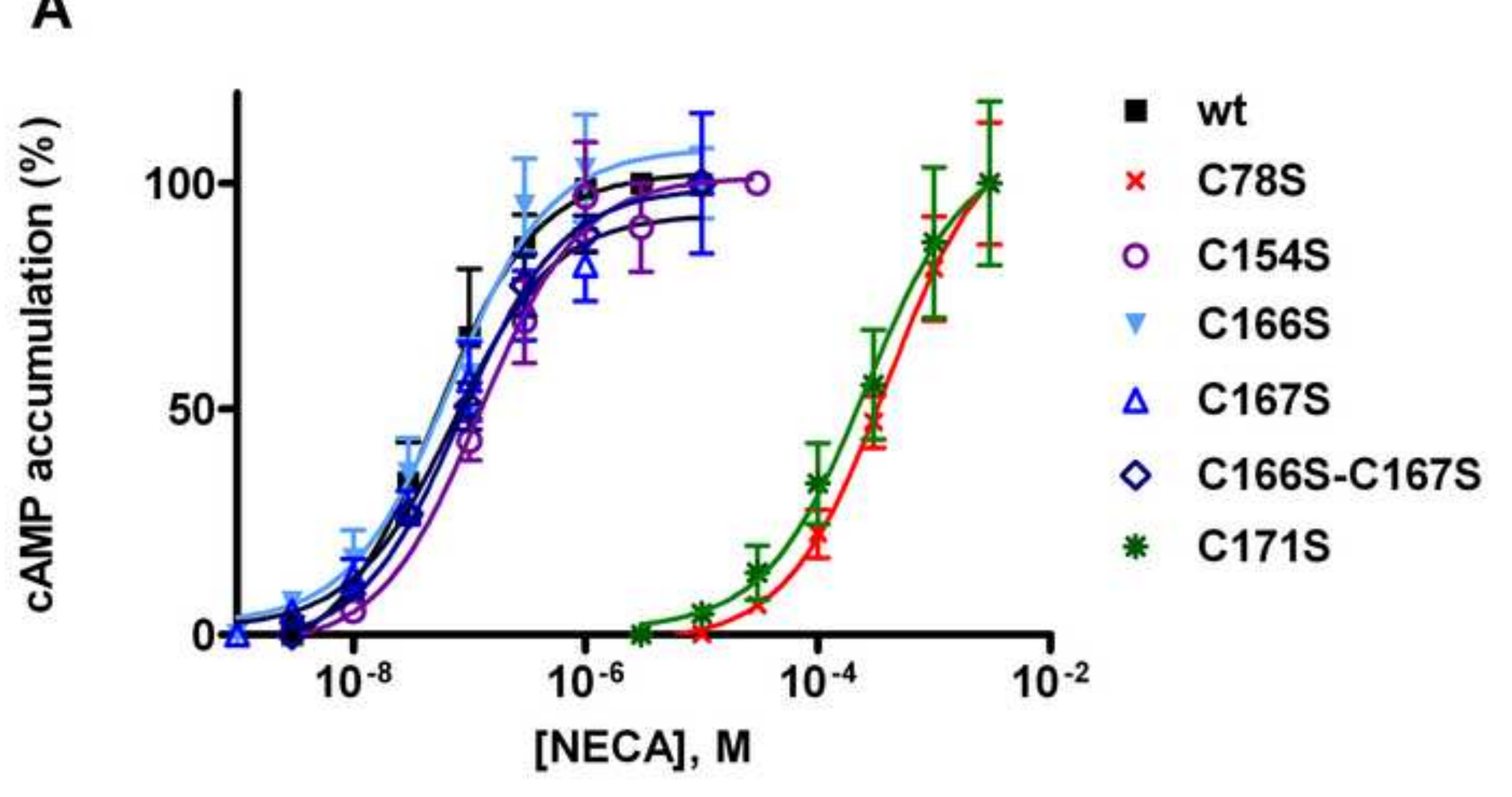

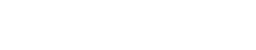




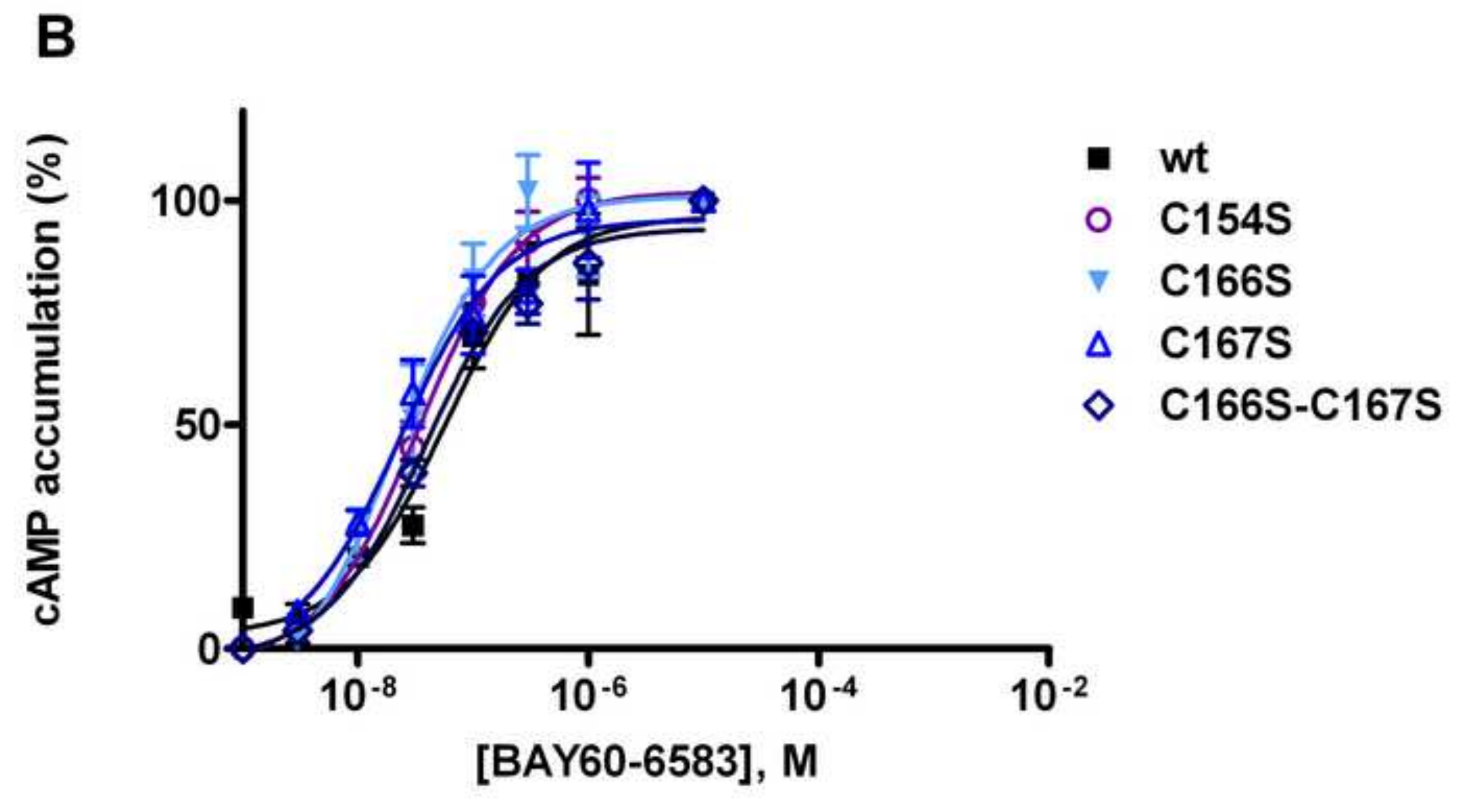

B

C154S 166S C1675 C166S-C167S

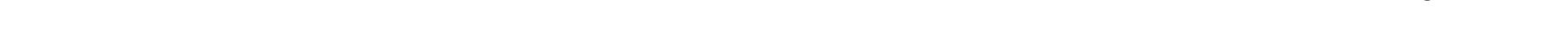


